Article

\title{
Potential PGPR Properties of Cellulolytic, Nitrogen-Fixing, Phosphate-Solubilizing Bacteria in Rehabilitated Tropical Forest Soil
}

\author{
Amelia Tang ${ }^{1}$, Ahmed Osumanu Haruna ${ }^{1,2,3, *}$, Nik Muhamad Ab. Majid ${ }^{3}$ and \\ Mohamadu Boyie Jalloh ${ }^{4}$ \\ 1 Faculty of Agriculture and Food Sciences, Universiti Putra Malaysia Bintulu Campus, \\ Bintulu 97008, Sarawak, Malaysia; ameliatang18@gmail.com \\ 2 Institute of Tropical Agriculture and Food Security (ITAFoS), Universiti Putra Malaysia, \\ Serdang 43400, Selangor, Malaysia \\ 3 Institute of Tropical Forestry and Forest Products (INTROP), Universiti Putra Malaysia, \\ Serdang 43400, Selangor, Malaysia; nik@upm.edu.my \\ 4 Faculty of Sustainable Agriculture, Universiti Malaysia Sabah, Sandakan Branch, Locked Bag No. 3, \\ Sandakan 90509, Sabah, Malaysia; mbjalloh@ums.edu.my \\ * Correspondence: osumanu@upm.edu.my
}

Received: 26 January 2020; Accepted: 20 February 2020; Published: 20 March 2020

\begin{abstract}
In the midst of the major soil degradation and erosion faced by tropical ecosystems, rehabilitated forests are being established to avoid the further deterioration of forest lands. In this context, cellulolytic, nitrogen-fixing (N-fixing), phosphate-solubilizing bacteria are very important functional groups in regulating the elemental cycle and plant nutrition, hence replenishing the nutrient content in forest soils. As is the case for other potential plant growth-promoting (PGP) rhizobacteria, these functional bacteria could have cross-functional abilities or beneficial traits that are essential for plants and can improve their growth. This study was conducted to isolate, identify, and characterize selected PGP properties of these three functional groups of bacteria from tropical rehabilitated forest soils at Universiti Putra Malaysia Bintulu Sarawak Campus, Malaysia. The bacteria were isolated based on their colonial growth on respective functional media, identified using both molecular and selected biochemical properties, and were assessed for their functional quantitative activities as well as PGP properties based on seed germination tests and indole-3-acetic acid (IAA) production. Out of the 15 identified bacterial isolates that exhibited beneficial phenotypic traits, a third belong to the genus Burkholderia and a fifth to Stenotrophomonas sp., with both genera consisting of members from two different functional groups. The results of the experiments confirm the multiple PGP traits of some selected bacterial isolates based on their respective high functional activities, root and shoot lengths, and seedling vigor improvements when bacterized on mung bean seeds, as well as significant IAA production. The results of this study suggest that these functional bacterial strains could potentially be included in bio-fertilizer formulations for crop growth on acid soils.
\end{abstract}

Keywords: rehabilitated forest; functional bacteria; cellulolytic activities; nitrogen-fixation activities; phosphate-solubilization activities; IAA production

\section{Introduction}

Although being vast in carbon and biodiversity, tropical ecosystems are facing major deforestation issues, leading to widespread soil erosion, which has garnered much recent attention [1-3]. As soil erosion episodes escalate, the resultant soil loss overrides soil establishment, which results in diminishing soil resources and the ecosystem supports they render $[4,5]$. This is manifested 
particularly as low productivity and farming sustainability on these degraded soils [6]. Planted forests or rehabilitation efforts are thus being undertaken to avoid further deterioration of forest lands.

Bacteria biodiversity and composition in soils is vast, resulting in major roles in principal soil processes that regulate whole terrestrial ecosystem operations. This occurs in nutrient and geochemical cycles, including for C, N, S, and P [7-9]. In plant litter mass, $20 \%-30 \%$ constitutes cellulose, making it the most abundant biopolymer [10]. The decomposition of cellulose is primarily due to soil microorganisms' activities, which assimilate the simple sugars resulting from the reduction process of complex polysaccharides [11,12]. Despite the generally better capabilities of fungi over bacteria in cellulose decomposition in soils $[13,14]$, these capabilities are also expressed by some phylogenetically different taxa of bacteria [11]. Previous reports have emphasized bacterial taxa, which have been recently discovered to possess cellulolytic capabilities, where they were formerly not known to have the capability to reduce cellulose $[15,16]$. Therefore, research on cellulolytic bacterial diversity in tropical soils is necessary.

The nitrogen needs of plants are supported by means of organic compound degradation and the atmospheric deposition of $\mathrm{N}$ and BNF, wherein BNF supplies $97 \%$ of the natural $\mathrm{N}$ reserves [17] via Bacteria and Archaea $[18,19]$. The $\mathrm{N}$ allocation in tropical ecosystems contributed to by $\mathrm{N}$-fixing microorganisms (diazotrophs), existing mostly in free-living conditions, can range from 12.2 to $36.1 \mathrm{~kg} \mathrm{ha}^{-1}$ year $^{-1}$ [20]. Considering the importance of free-living diazotrophic communities to ecosystem processes, there is a need to broaden our knowledge on their diversity in rehabilitated tropical forests due to a dearth of such information.

In most tropical soils, which are usually very acidic, $\mathrm{P}$ is one of the most common deficient macronutrients, due to high soil $\mathrm{Al}$ and/or Fe levels, in which P is fixed as insoluble mineral complexes, causing the unavailability of $P$ for root uptake [21]. Apart from chemical amendments, microorganisms have also been applied over the years to improve nutrient availability, especially $\mathrm{P}$ in soils, as well as for alleviating $\mathrm{Al}$ toxicity [22]. Furthermore, tropical acid soils support only limited acid-tolerant plant species and microbes. In soils, phosphate-solubilizers are predominatly bacteria compared to fungi with values of $1 \%-50 \%$ and $0.1 \%-0.5 \%$, of the total population, respectively [23]. Bacterial strains comprising Pseudomonas, Bacillus, and Rhizobium have been cited to be the dominant phosphate-solubilizers [24]. In addition, Burkholderia strains and species that occur in broadly different natural niches have been frequently reported as plant-associated bacteria, despite their prevalence as free-living in the rhizosphere, as well as epiphytic or endophytic, obligate endosymbionts, or phytopathogens [25]. The PSB can release substantial amounts of organic acids crucial for fixing $\mathrm{Al}$ via a chelation process, thus reducing $\mathrm{Al}$ toxicity to plant roots in highly weathered soils [26].

As with other potential PGPB, these functional bacteria could have cross-functional abilities or beneficial traits, apart from their primary functional abilities, such as the production of plant growth-promoting (PGP) phytohormones, polysaccharides, and organic acids that are essential for plant growth and development [22]. In addition, the indole-3-acetic acid (IAA) produced by bacteria stimulates shoot elongation and/or in particular root structures [27], which could result in more efficient elemental nutrient acquisition by host plants, leading to higher plant growth and development. The adoption of functional bacterial strains with multiple functional and PGP traits in crop production could promote sustainable crop productivity, offer an option for minimizing costs related to chemical fertilizer application and reduce pollution risks from excessive application of chemical fertilizers.

However, the isolation and characterization of these three particular types of potential functional bacteria from tropical soils of rehabilitated forests remain scarce. Thus, the aims of this study were to: 1) isolate and identify cellulolytic, $\mathrm{N}$-fixing, and phosphate-solubilizing bacteria from a rehabilitated tropical forest soil, and 2) characterize cellulolytic, N-fixing, and phosphate-solubilizing bacteria for their respective functional activities, such as IAA production, early plant growth promotion and some phenotypic and biochemical properties. 


\section{Materials and Methods}

\subsection{Soil Sampling and Physico-Chemical Properties}

Soil samples were collected from a rehabilitated forest site at Universiti Putra Malaysia Bintulu Sarawak Campus, Malaysia, through random sampling method using aseptic techniques near the rhizospheric zones of planted trees. Soil samples were collected at 0-10 cm depth using an auger for various analyses. The soil samples were mixed thoroughly and kept in tightly sealed plastic bags and stored at $4{ }^{\circ} \mathrm{C}$ (for less than three days before bacterial analysis).

The soil at the study area belonged to Bekenu and Nyalau series (Ultisols) and was characterized as well-drained, red-yellow to yellow, siliceous, isohyperthermic fine loamy Typic Tualemkuts based on the USDA-Soil Taxonomy Classification System. The soil is a sandy loam texture containing $69.18 \%$ sand, $13.27 \%$ silt, and $17.55 \%$ clay. The soil is acidic with $\mathrm{pH} 4.71$ and a CEC value of $8.13 \mathrm{cmol}_{\mathrm{C}} \mathrm{kg}^{-1}$. The exchangeable $\mathrm{K}, \mathrm{Ca}$, and $\mathrm{Mg}$ contents were $0.10,6.68$, and $45.33 \mathrm{cmol}_{\mathrm{C}} \mathrm{kg}^{-1}$, respectively. The total $\mathrm{N}$, total $\mathrm{C}$, and organic matter content were $0.13,2.60$, and $4.48 \%$, respectively. The available $\mathrm{P}$, exchangeable ammonium, and available nitrate in the soil were $6.22,42.73$, and $1.40 \mathrm{mg} \mathrm{kg}^{-1}$, respectively.

\subsection{Isolation and Plate Assays of Functional Bacteria}

Five grams of fresh soil was mixed into $100 \mathrm{~mL}$ of sterile distilled water and shaken at $150 \mathrm{rpm}$ for $24 \mathrm{~h}$. The supernatant was serially diluted by ten-folds, and $0.1 \mathrm{~mL}$ aliquots were spread over Petri dishes containing the respective selective media in triplicates.

Nitrogen-fixing bacterial colonies were isolated on $\mathrm{N}$-free malate $(\mathrm{Nfb})$ medium [28] with some modifications. Details of the medium per liter were as follows: $0.4 \mathrm{~g}$ of $\mathrm{KH}_{2} \mathrm{PO}_{4}, 0.1 \mathrm{~g}$ of $\mathrm{K}_{2} \mathrm{HPO}_{4}$, $0.2 \mathrm{~g}$ of $\mathrm{MgSO}_{4} .7 \mathrm{H}_{2} \mathrm{O}, 0.1 \mathrm{~g}$ of $\mathrm{NaCl}, 0.02 \mathrm{~g}$ of $\mathrm{CaCl}_{2}, 0.01 \mathrm{~g}$ of $\mathrm{FeCl}_{3}, 0.002 \mathrm{~g}$ of $\mathrm{MoO}_{4} \mathrm{Na}_{2} \mathrm{H}_{2} \mathrm{O}, 5.0 \mathrm{~g}$ of sodium malate, and $5 \mathrm{~mL}$ of bromothymol blue with $0.5 \%$ alcohol solution and $20.0 \mathrm{~g}$ of agar, with whole content adjusted to $\mathrm{pH}$ 7. The colonies that fix $\mathrm{N}_{2}$ alkalinize the culture medium (blue) because of ammonia production.

Phosphate-solubilizing bacterial colonies were isolated on tricalcium phosphate as insoluble phosphate-containing media to differentially isolate phosphate-solubilizing bacteria based on the formation of clear zones around their colonies [29-32] with some modifications. All media had $50 \mathrm{~mL}$ of a salts solution $\left(\mathrm{MgCl}_{2} \cdot 6 \mathrm{H}_{2} \mathrm{O}, 100 \mathrm{~g} \mathrm{~L}^{-1} ; \mathrm{MgSO}_{4} \cdot 7 \mathrm{H}_{2} \mathrm{O}, 5 \mathrm{~g} \mathrm{~L}^{-1} ; \mathrm{KCl}, 4 \mathrm{~g} \mathrm{~L}^{-1} ;\left(\mathrm{NH}_{4}\right)_{2} \mathrm{SO}_{4}, 2 \mathrm{~g} \mathrm{~L}^{-1}\right)$, $10 \mathrm{~g}$ of sucrose as $\mathrm{C}$ source, $20 \mathrm{~g} \mathrm{~L}^{-1}$ of agar and $2.5 \mathrm{~g}$ of tricalcium phosphate, $\mathrm{Ca}_{3}\left(\mathrm{PO}_{4}\right)_{2}$, with $6 \mathrm{~mL} \mathrm{~L}^{-1}$ of bromophenol blue in $0.4 \%$ ethanol solution added to the media and content $\mathrm{pH}$ adjusted to 7 .

Cellulolytic bacterial colonies were isolated on modified cellulose-Congo red agar from Hendricks et al. [33] per liter, comprising: $0.50 \mathrm{~g}$ of $\mathrm{K}_{2} \mathrm{HPO}_{4}, 0.25 \mathrm{~g}$ of $\mathrm{MgSO}_{4}, 1.88 \mathrm{~g}$ of cellulose microgranular powder, $0.20 \mathrm{~g}$ of Congo red, $5.00 \mathrm{~g}$ of agar, $2.00 \mathrm{~g}$ of gelatin, $100 \mathrm{~mL}$ of soil extract, and $900 \mathrm{~mL}$ of tap water (used to provide essential trace elements for soil bacteria), with content adjusted to $\mathrm{pH}$ 7. The colonies exhibiting zones of clearing would indicate cellulose-hydrolyzing activities.

After spread-plating, all media were incubated at $30^{\circ} \mathrm{C}$. Some colonies exhibiting large and instant blue halo or clearing zones on respective media were isolated, purified on new respective selective media, sub-cultured on agar slants, and stored at $4{ }^{\circ} \mathrm{C}$ for further studies. Plate assays of selected functional bacterial isolates were also done by spot-inoculating cultures in triplicates on the respective aforementioned media and incubated at $30^{\circ} \mathrm{C}$ over 10 day-periods prior to the assessment of their functional activity efficiency, based on calculations by ratio of total diameter (colony and halo or clearing zone around colonies) and colony diameter [34]. 


\subsection{Quantitative Assays for Functional Activities}

\subsubsection{Quantitative Assay for Cellulase Activity}

Cellulolytic isolates were cultured in nutrient broth, shaken at $120 \mathrm{rpm}$ at $30{ }^{\circ} \mathrm{C}$ for $16 \mathrm{~h}$, and the size of the pre-inoculum culture for cellulase assay was fixed to $\mathrm{OD}_{600}=0.5\left(10^{6}\right.$ to $\left.10^{7} \mathrm{cfu} \mathrm{mL}^{-1}\right)$. A total of $1 \mathrm{~mL}$ of each pre-inoculum was seeded in $40 \mathrm{~mL}$ cellulose broth as a basal medium. The composition of the cellulose broth per liter was: $5.0 \mathrm{~g} \mathrm{~L}^{-1}$ cellulose microgranular, $2.5 \mathrm{~g} \mathrm{~L}^{-1} \mathrm{NaNO}_{3}, 1.0 \mathrm{~g} \mathrm{~L}^{-1}$ $\mathrm{KH}_{2} \mathrm{PO}_{4}, 0.6 \mathrm{~g} \mathrm{~L}^{-1} \mathrm{MgSO}_{4} \cdot 7 \mathrm{H}_{2} \mathrm{O}, 0.1 \mathrm{~g} \mathrm{~L}^{-1} \mathrm{NaCl}, 0.1 \mathrm{~g} \mathrm{~L}^{-1} \mathrm{CaCl}_{2} \cdot 6 \mathrm{H}_{2} \mathrm{O}, 0.01 \mathrm{~g} \mathrm{~L}^{-1} \mathrm{FeCl}_{3}, 2.0 \mathrm{~g} \mathrm{~L}^{-1}$ gelatin and $0.1 \mathrm{~g} \mathrm{~L}^{-1}$ yeast extract with $\mathrm{pH}$ 6.8-7.2 (modified from Lu et al. [35]). The inoculated broth was incubated at $30{ }^{\circ} \mathrm{C}$ under agitation at $180 \mathrm{rpm}$ and CMCase activity was analyzed for up to 5 days. For CMCase activity, $0.5 \mathrm{~mL}$ culture filtrate from broth as crude enzyme source, or supernatant cellulase, also specified as CMCase, was incubated with $1 \mathrm{~mL}$ of $1 \%$ carboxymethylcellulose in $0.1 \mathrm{M}$ citrate buffer, $\mathrm{pH} 5$ at $40{ }^{\circ} \mathrm{C}$ in agitation for $30 \mathrm{~min}$. The amount of reducing sugars (glucose) was measured using the Somogyi-Nelson method [36,37] at $520 \mathrm{~nm}$. One unit of enzyme activity (IU mL $\left.{ }^{-1}\right)$ is equivalent to the amount of enzyme per mL of culture filtrate that liberates $1 \mu \mathrm{g}$ of glucose per minute [38].

\subsubsection{Quantitative Assay for In Vitro BNF Activity}

The procedure for quantitative estimation of BNF activity was modified from those described by Soares et al. [39]. Each N-fixing isolate was grown as a pre-inoculum in nutrient broth under agitation at $120 \mathrm{rpm}$ at $30^{\circ} \mathrm{C}$ for $16 \mathrm{~h}$. Optical density was used to adjust the inoculum size OD $_{600}=0.5$ is equivalent to $10^{6}$ to $10^{7}$ colony forming units (cfu) $\mathrm{mL}^{-1}$ ]. The inoculum was then transferred $(100 \mu \mathrm{L})$ to new media, $\mathrm{NFb}$ broth (containing similar composition as $\mathrm{Nfb}$ medium with the exception of agar). The inoculated media was incubated at $30{ }^{\circ} \mathrm{C}$ under constant agitation for $72 \mathrm{~h}$ for $\mathrm{N}_{2}$ fixation quantification. A control medium was also included by using a $100 \mu \mathrm{L}$ nutrient broth as inoculant. The amount of $\mathrm{N}_{2}$ fixation was measured by sulfur digestion and distilled with $\mathrm{NaOH} 10 \mathrm{~mol} \mathrm{~L}^{-1}$, as described by Bremner and Keeney [40]. There were triplicates of the preparation. The samples were digested with $2 \mathrm{~mL}$ of concentrated $\mathrm{H}_{2} \mathrm{SO}_{4}(d=1.84), 1 \mathrm{~mL}$ of $\mathrm{H}_{2} \mathrm{O}_{2} 30 \%$ and $0.7 \mathrm{~g}$ of the digestion mixture $\left(100 \mathrm{~g} \mathrm{Na}_{2} \mathrm{SO}_{4}+10 \mathrm{~g} \mathrm{CuSO}_{4} .5 \mathrm{H}_{2} \mathrm{O}+1 \mathrm{~g}\right.$ selenium $)$ at $350-375^{\circ} \mathrm{C}$. The products of the digestion were distillated with $10 \mathrm{~mL}$ of $\mathrm{NaOH} 10 \mathrm{~mol} \mathrm{~L}^{-1}$, and the ammonia trapped in $10 \mathrm{~mL}$ of $2 \%$ boric acid was measured by titration with $0.0025 \mathrm{~mol} \mathrm{~L}^{-1} \mathrm{H}_{2} \mathrm{SO}_{4}$.

\subsubsection{Quantitative Assay for Inorganic Phosphate-solubilization Activity}

The quantitative estimation of inorganic phosphate-solubilization was done with some modifications from Delvasto et al. [41]. Pre-inoculum cultures were prepared earlier by inoculating phosphate-solubilizing isolates in nutrient broth under agitation at $120 \mathrm{rpm}$ at $30{ }^{\circ} \mathrm{C}$ for $16 \mathrm{~h}$. The inoculum size was adjusted to $\mathrm{OD}_{600}=0.5\left(10^{6}\right.$ to $\left.10^{7} \mathrm{cfu} \mathrm{mL}^{-1}\right)$. Prior to the assay, pre-inoculum cultures were washed 3 times and resuspended using saline solution $0.85 \% \mathrm{NaCl}$ and one $\mathrm{mL}$ isolate suspension was inoculated into a $100 \mathrm{~mL}$ liquid medium containing insoluble tricalcium phosphate, as in the solid medium but without agar. Inoculated broth was incubated at $30{ }^{\circ} \mathrm{C}$ under agitation at $180 \mathrm{rpm}$ for up to 5 days. Saline solution without inoculant in the broth was left as the control. Soluble $\mathrm{P}$ content in culture filtrates was determined using the blue method [42] and UV-vis spectrophotometer at $882 \mathrm{~nm}$. The final $\mathrm{pH}$ of the liquid medium was measured using a $\mathrm{pH}$ meter. All values of $\mathrm{pH}$ and $\mathrm{P}$ concentrations of the samples were measured in triplicates.

\subsubsection{Morphological and Physiological Characterization of Selected Isolates}

Selected isolates were individually studied for morphological and phenotypic properties. They were examined microscopically using a spore-staining procedure according to the Schaeffer-Fulton method and the standard Gram staining procedure described by Cappuccino and Sherman [43]. Biochemical tests and physiological activities, or differential growth tests, were also carried out. Citrate utilization was determined on Simmons citrate agar; hydrogen sulfide production, along with lactose 
and glucose fermentation were determined on Kligler Iron Agar; Gram negative strains and lactose fermentation were detected using Mac Conkey agar; gelatinase production, starch hydrolysis, casein proteolysis, lipase production, and indole production were each determined using nutrient gelatine, starch agar, skim milk agar, Tween 80 agar and BD's Indole Reagent Droppers (modified Kovacs' reagent) via the standard tube method, respectively. Catalase test was done using $3 \%$ hydrogen peroxide solution. A motility test was conducted on Biolife's Motility Medium, whereas the nitrate reduction test was done using the test kit by Fluka (Fluka 73426, Sigma-Aldrich, Germany). The aforementioned physiological and biochemical test results were processed and compared with the results of systematic bacteriology identification according to Bergey's Manual of Determinative Bacteriology and Bergey's Manual of Systematic Bacteriology [44,45].

\subsection{Molecular Method for Bacterial Identification}

\subsubsection{Deoxyribonucleic Acid Extraction}

Bacterial genomic DNA was extracted using the sodium dodecyl sulfate (SDS) method. Bacterial inoculum from overnight streaked culture plate was recultured overnight in $1.5 \mathrm{~mL}$ of nutrient broth in capped tubes with one control (broth without inoculum) in the water bath shaker at $30^{\circ} \mathrm{C}$. The $1.5 \mathrm{~mL}$ cell suspension was centrifuged at $13,040 \times g$ for $3 \mathrm{~min}$ at $4{ }^{\circ} \mathrm{C}$. After removing the supernatant, the cells were resuspended or washed with $180 \mu \mathrm{L}$ of TE buffer (10 mM Tris, 1mM EDTA, pH 8.0) by vortex-mixing and incubated on ice for $5 \mathrm{~min}$. A total of $75 \mu \mathrm{L}$ of $2 \%$ SDS solution was added, followed by an invert-mixing step and incubation on ice for 5-10 min. Then, $250 \mu \mathrm{L}$ of $3 \mathrm{M}$ potassium acetate was added, followed by gentle invert-mixing and incubation on ice for $5 \mathrm{~min}$. The sample was centrifuged at $13,040 \times g$ for $5 \mathrm{~min}$ at $4{ }^{\circ} \mathrm{C}$. The supernatant containing bacterial DNA was carefully transferred to a clean $1.5 \mathrm{~mL}$ tube on ice. Absolute ethanol was then added at approximately two times the volume of the supernatant in the same tube, invert-mixed followed by centrifugation at $12,000 \times g$ for $10 \mathrm{~min}$ at $4{ }^{\circ} \mathrm{C}$. The supernatant was discarded, and $1 \mathrm{~mL}$ of $75 \%$ ethanol was added to the DNA pellet. The pellet was resuspended by gently pipette-mixing the suspension followed by centrifugation at $12,000 \times \mathrm{g}$ for $10 \mathrm{~min}$ at $4{ }^{\circ} \mathrm{C}$. The supernatant was discarded, and the pellet was air-dried. Finally, $20 \mu \mathrm{L}$ of TE buffer (10 mM Tris, 1mM EDTA, $\mathrm{pH}$ 8.0) was added, pipette-mixed gently, and stored at $-20^{\circ} \mathrm{C}$.

\subsubsection{Polymerase Chain Reaction Amplification of Extracted DNA}

The amplification of DNA extraction products was performed in a final volume of $25 \mu \mathrm{L}$ each. For each reaction, $1.25 \mu \mathrm{L} 0.5 \mu \mathrm{M}$ for both of the primers (16S-F and 16S-R1), $2.5 \mu \mathrm{L} 25 \mathrm{mM} \mathrm{MgCl}_{2}, 2.5 \mu \mathrm{L} 10 \mathrm{X}$ reaction buffer [ $\left.\left(\mathrm{NH}_{4}\right)_{2} \mathrm{SO}_{4}\right], 0.5 \mu \mathrm{L}$ working stock dNTPs or dNTP mix combined to give a final concentration of $0.2 \mathrm{mM}$ each, $0.25 \mu \mathrm{L}$ of Taq DNA Polymerase $(5 \mathrm{U} / \mu \mathrm{L}), 15.75 \mu \mathrm{L}$ of sterilized distilled water and $1 \mu \mathrm{L}$ of template DNA. Primers 16S-F and 16S-R1 had the sequences of $5^{\prime}$-AAGAGTTTGATCATGGCTCA-3' and 5'-TAAGGA GGTGATCCAACCGCAGGTTC-3' ${ }^{\prime}$, respectively. The PCR was performed in a thermal cycler (Bioer XP Cycler) using cycling conditions consisting of an initial denaturation at $95^{\circ} \mathrm{C}$ for $3 \mathrm{~min}$, followed by 35 cycles consisting of denaturation at $94{ }^{\circ} \mathrm{C}$ for $30 \mathrm{~s}$, annealing at $50{ }^{\circ} \mathrm{C}$ for $30 \mathrm{~s}$, and extension at $72{ }^{\circ} \mathrm{C}$ for $1 \mathrm{~min}$. A final extension was performed at $72{ }^{\circ} \mathrm{C}$ for $5 \mathrm{~min}$. A blank that contained all the components of the reaction mixture without the DNA template was included as a control. The PCR products were analyzed by running on $1 \%$ agarose gel electrophoresis.

\subsubsection{Agarose Gel Electrophoresis}

A $1 \%(\mathrm{w} / \mathrm{v})$ agarose gel was prepared by mixing $0.25 \mathrm{~g}$ of agarose in $25 \mathrm{~mL}$ of $1 \mathrm{X}$ TAE buffer and placed onto an electrophoresis tank submerged in 1X TAE buffer solution. The loading samples were each prepared by mixing $5 \mu \mathrm{L}$ of PCR products with $3 \mu \mathrm{L}$ of $6 x$ loading dye and $1 \mu \mathrm{L}$ of EZ Vision dye, whereas $1 \mu \mathrm{L}$ of loading DNA marker or ladder bearing $1.5 \mathrm{~kb}$ size was mixed with $2 \mu \mathrm{L}$ of $6 \mathrm{x}$ loading 
dye, $1 \mu \mathrm{L}$ of EZ Vision dye, and $5 \mu \mathrm{L}$ of $1 \mathrm{x}$ TAE buffer solution before being run at $90 \mathrm{~V}$ and visualized using UV light in a gel imager (Alpha Innotech FluorChem 5500 Gel Imaging System, Cambridge, Massachusetts, USA). A scale-up of PCR products at $50 \mu \mathrm{L}$ and purification of PCR products were done before sending them out for outsourced sequencing service.

\subsubsection{Purification of PCR Products for Sequencing}

Direct precipitation is a general method used for the purification of PCR products. A total of $50 \mu \mathrm{L}$ of PCR products was transferred to a $1.5 \mathrm{~mL}$ tube. Sodium acetate $(\mathrm{pH}$ ) at $4 \mu \mathrm{L}$ and absolute ethanol (99\%) at $100 \mu \mathrm{L}$ were then added, mixed, and kept in ice for $30 \mathrm{~min}$. The tube was centrifuged at $13,040 \times \mathrm{g}$ for $15 \mathrm{~min}$ at $4{ }^{\circ} \mathrm{C}$. The supernatant was decanted and $200 \mu \mathrm{L}$ of $75 \%$ ethanol was added and vortex-mixed for $1 \mathrm{~min}$. The tube was centrifuged at $13,040 \times \mathrm{g}$ for $5 \mathrm{~min}$ at $4{ }^{\circ} \mathrm{C}$. The pellet was then air-dried and $15 \mu \mathrm{L}$ of sterile distilled water was added to re-suspend the pellet by tapping. Prior to being sent for sequencing, the quantification or estimation of the concentration of the PCR products within the range of 5 to $100 \mathrm{ng}$ per $\mu \mathrm{L}$ was done using the Gel Imager Software (Alpha Innotech FluorChem 5500 Gel Imaging System, Cambridge, Massachusetts, USA)

\subsubsection{Sequencing of $16 \mathrm{~S}$ rDNA}

The determination of the $16 \mathrm{~S}$ rDNA nucleotide sequences was done by transferring the purified PCR products containing the concentrated amplified DNA, along with primer R2 to First BASE Laboratories Sdn Bhd, a life-sciences-based research company located in Peninsular Malaysia.

\subsubsection{Identification of Bacterial Sequences}

The sequences obtained for selected bacterial isolates were manually analyzed using Sequence Scanner Software v1.0 by Applied Biosystems ${ }^{\circledR}$ (Forster City, California, USA). The interpretation of the sequences was facilitated by comparing them with information in the BLAST database online (National Centre for Biotechnology Information, Bethesda, Maryland, USA) in which the identification of an isolate is generated with percentages of matched database nucleotide sequences and the calculation of the statistical significance of matches.

\subsection{Plant Growth-promoting Assays}

\subsubsection{Germination Assays of Maize and Green Gram Seeds}

Phytotoxic assays for 15 selected bacterial inoculants on green gram (Vigna radiata) seeds obtained from a local market were done via germination check of both root and shoot of the germinating seeds. The seeds were surface-sterilized in $0.1 \%$ sodium hypochlorite solution for $5 \mathrm{~min}$ and were then rinsed at least three times with sterile distilled water before soaking in broth containing $16 \mathrm{~h}$ bacterial cultures, according to treatments, for $2 \mathrm{~h}$ at $30^{\circ} \mathrm{C}$. The seed treatments consisted of 15 selected isolate cultures. Two control treatments were included whereby the first control comprised seeds treated with sterile distilled water and the other control comprised treatments with sterile nutrient broth.

The treated green gram seeds were placed on petri dishes containing sterilized moist sheets of Whatman filter paper for each treatment. Each treatment was based on 100 seeds of each plant type. The seeds were incubated for up to 7 days at about $30^{\circ} \mathrm{C}$ and moisture content of growth support was maintained with an equal volume of autoclaved distilled water on daily basis. The number of germinated green gram seeds was counted on the third and fourth day of incubation, respectively, followed by a second counting and measurement of the shoots and roots or radicle length for both plants types on the seventh day. The percentage of germinated seeds and the vigor index were calculated. The vigor index was calculated as the sum of the mean shoot and root length multiplied by the percentage of germination [46]. All experimental sets and apparatus used were sterilized where necessary. 


\subsubsection{Indole-3-Acetic Acid Production Assay}

Some selected bacterial isolates were subjected to an in vitro colorimetric determination of IAA production using Salkowski's reagent ( $2 \%$ of $0.5 \mathrm{M} \mathrm{FeCl}_{3}$ in $35 \%$ perchloric acid), as modified from Asghar et al. [47]. Each selected isolate was grown to exponential growth phase (OD $\geq 1.0)$ within $16 \mathrm{~h}$ to be used as pre-inoculum for the bioassay. The inoculum was adjusted to $\mathrm{OD}_{600}=0.5$ $\left(10^{6}\right.$ to $\left.10^{7} \mathrm{cfu} \mathrm{mL}{ }^{-1}\right)$ before inoculation at $500 \mu \mathrm{L}$ into $50 \mathrm{~mL}$ of nutrient broth without the addition of tryptophan and was incubated at $30{ }^{\circ} \mathrm{C}$ under agitation at $100 \mathrm{rpm}$ for up to $48 \mathrm{~h}$. Non-inoculated broth was included as the control. Each culture was centrifuged at $10,000 \mathrm{rpm}$ for $10 \mathrm{~min}$ at $4{ }^{\circ} \mathrm{C}$. A total of $1 \mathrm{~mL}$ of culture supernatant was mixed with $2 \mathrm{~mL}$ of Salkowski's reagent in a test tube and kept in the dark for 20-25 min before measuring absorbance using a UV-Vis spectrophotometer at $535 \mathrm{~nm}$. The assay for each isolate was conducted in triplicates. Any appearance of a reddish to pinkish color in the solution indicated IAA presence in the cultured medium, and, depending on the color intensity of the test solutions, the coloring responses were classified into two categories: pink type (pale pink to deep pink) and red type (dark red to red).

\subsection{Data Analysis of Bioassays}

An Analysis of Variance (ANOVA) was used to test for significant differences between measurements of each bioassay, whereas Tukey's Test was employed to test for significant differences among the different treatments at $p \geq 0.05$. The Statistical Analysis System (SAS Ver. 9.2, Cary, NC, USA) was used for the analysis.

\section{Results and Discussion}

\subsection{Functional Activity Assays of Respective Isolates}

In this study, 14 out of 62 cellulolytic, 12 out of $39 \mathrm{~N}$-fixing, and 8 out of 36 phosphate-solubilizing bacterial isolates obtained from the rhizospheres of both planted and indigenous tree species in the rehabilitated forest were screened based on their functional activities on their respective selective media and distinct morphology, for further characterization. Among the three functional groups, the phosphate-solubilizing group had the least number of characterized isolates due to the fact that PSB isolates tend to lose their ability after successive transfers or subcultures on agar medium, as has been reported previously [48]. Diazotrophic isolates also encountered a similar phenomenon whereby, upon successive cultivation, some isolates failed to develop blue haloes or were unable to grow on $\mathrm{N}$-free media. A report by da Silva et al. [49] showed that diazotrophic isolates lose their characteristic pellicle growth upon successive cultures, which makes nitrogenase activity assessment not possible. However, none of the cellulolytic isolates tested in this study lost their functional ability.

Cellulolytic microorganisms play a major role in the synthesis of cellulases crucial for the breakdown of complex polysaccharides into simple sugars. There was no specific correlation between cellulose-hydrolyzing efficiency and cellulase (CMCase) activity for the 14 tested cellulolytic strains (Table 1). Among the 14 cellulolytic isolates assessed, isolates C46d and C42d consistently showed higher cellulolytic activity, based on both cellulose-hydrolyzing efficiency (10.41 and 8.52, respectively) and cellulase activity $\left(0.089 \mathrm{U} \mathrm{mL}^{-1}\right.$ and $0.077 \mathrm{U} \mathrm{mL}^{-1}$, respectively). The cellulase (CMCase) activities of the cellulolytic isolates in this study were comparable to those of bacterial strains isolated from soil under different culture conditions, as reported by Sethi et al. [50]. The cellulase (CMCase) activity demonstrated by C46d was especially high compared to those reported for Bacillus amyloliquefaciens SS35 [51] and Bacillus pumilus EB3 [52] at $0.079 \mathrm{U} \mathrm{mL}^{-1}$.

For nitrogenase activity assessment, there was a positive relationship $(\mathrm{r}=0.63, p \leq 0.05)$ between the N-fixing efficiency values and BNF amount. Among the 12 diazotrophic isolates evaluated, NB1 exhibited the most active N-fixing activity, as demonstrated by the consistently higher means of both activity efficiency and nitrogenase activity quantification at 10.82 and $2.21 \mu \mathrm{g} \mathrm{N} \mathrm{mL} \mathrm{Nay}^{-1}$, respectively (Table 2). NB11 also presented comparably high $\mathrm{N}$-fixing activity at $1.87 \mu \mathrm{g} \mathrm{N} \mathrm{mL}{ }^{-1} \mathrm{day}^{-1}$, 
although it produced a fairly small halo on the plate assay, yielding a mean efficiency value of 1.88 . Strain N20c had the second highest mean for $\mathrm{N}$-fixing efficiency (5.92) but displayed a fairly moderate amount of $\mathrm{N}$-fixing activity $\left(1.24 \mu \mathrm{g} \mathrm{N} \mathrm{mL}{ }^{-1}\right.$ day $\left.^{-1}\right)$. Lower $\mathrm{N}$-fixing activity was recorded for the rest of the assessed isolates, with values ranging from 0.34 to $1.38 \mu \mathrm{g} \mathrm{N} \mathrm{mL}{ }^{-1}$ day $^{-1}$. Plate assays revealed the lowest $\mathrm{N}$-fixing efficiency values in the range 1.75-2.67. Although there is a lack of reports on $\mathrm{N}$-fixing activity (efficiency) evaluation based on plate assays, the quantitative values were within the range of that for other reported diazotrophic strains [39]. The ability of diazotrophic bacteria to convert atmospheric $\mathrm{N}_{2}$ into ammonia, which is the available form of $\mathrm{N}$ used by living organisms for biosynthesis, is undeniably of vital importance to soil systems, especially due to the direct influence on plant growth or indirectly due to the production of phytohormones that boost plant growth $[49,53]$.

Table 1. Cellulose-hydrolyzing efficiency and cellulase (CMCase) activities ( $\mathrm{U} \mathrm{mL}^{-1}$ cell-free culture broth after 5 days at $30^{\circ} \mathrm{C}, 180 \mathrm{rpm}$, and medium $\mathrm{pH}$ 7) of cellulolytic isolates.

\begin{tabular}{ccc}
\hline Isolates & Activity Efficiency & Cellulase Activity $\left(\mathbf{U ~ m L}^{\mathbf{- 1}}\right)$ \\
\hline \multicolumn{3}{c}{ Mean Value \pm S.E. } \\
\hline C14 & $5.25^{\mathrm{b}, \mathrm{c}} \pm 1.50$ & $0.016^{\mathrm{f}} \pm 0.002$ \\
C39d & $5.10^{\mathrm{b}, \mathrm{c}} \pm 0.44$ & $0.015^{\mathrm{f}} \pm 0.002$ \\
C41d & $5.29^{\mathrm{b}, \mathrm{c}} \pm 0.88$ & $0.078^{\mathrm{b}} \pm 0.001$ \\
C42d & $8.52^{\mathrm{a}, \mathrm{b}} \pm 1.93$ & $0.077^{\mathrm{b}} \pm 0.001$ \\
C46d & $10.41^{\mathrm{a}} \pm 0.43$ & $0.089^{\mathrm{a}} \pm 0.001$ \\
C22b & $10.31^{\mathrm{a}} \pm 0.62$ & $0.035^{\mathrm{e}} \pm 0.001$ \\
C34c & $4.57^{\mathrm{c}} \pm 3.24$ & $0.047^{\mathrm{d}} \pm 0.001$ \\
C45d & $5.93^{\mathrm{b}, \mathrm{c}} \pm 1.23$ & $0.059^{\mathrm{c}} \pm 0.001$ \\
C4 & $3.59^{\mathrm{c}} \pm 0.14$ & $0.079^{\mathrm{b}} \pm 0.002$ \\
C25b & $3.70^{\mathrm{c}} \pm 0.79$ & $0.078^{\mathrm{b}} \pm 0.001$ \\
C29b & $5.57^{\mathrm{b}, \mathrm{c}} \pm 0.70$ & $0.080^{\mathrm{b}} \pm 0.001$ \\
C40d & $4.63^{\mathrm{c}} \pm 0.61$ & $0.077^{\mathrm{b}} \pm 0.001$ \\
C43d & $4.60^{\mathrm{c}} \pm 2.26$ & $0.078^{\mathrm{b}} \pm 0.001$ \\
CB15 & $5.54^{\mathrm{b}, \mathrm{c}} \pm 0.36$ & $0.060^{\mathrm{c}} \pm 0.001$
\end{tabular}

S.E. is standard error of the mean. Means with the same letter are not significantly different at $p \geq 0.05$ within columns using Tukey's test.

Table 2. Nitrogen-fixation efficiency and the BNF quantification of diazotrophic isolates.

\begin{tabular}{|c|c|c|}
\hline Isolate & Activity Efficiency & $\begin{array}{l}\text { Quantitative Activity } \\
\left(\mu \mathrm{g} \mathrm{N} \mathrm{mL} \mathrm{m}^{-1} \text { day }^{-1}\right)\end{array}$ \\
\hline \multicolumn{3}{|c|}{ Mean Value \pm S.E. } \\
\hline NB1 & $10.82^{a} \pm 0.26$ & $2.21^{\mathrm{a}} \pm 0.34$ \\
\hline NB4 & $1.84^{\mathrm{e}} \pm 0.05$ & $1.11^{\mathrm{c}, \mathrm{d}} \pm 0.27$ \\
\hline NB5 & $2.03^{e} \pm 0.06$ & $0.65^{\mathrm{c}, \mathrm{d}} \pm 0.00$ \\
\hline NB7 & $1.97^{\mathrm{e}} \pm 0.05$ & $1.23^{b, c} \pm 0.24$ \\
\hline NB8 & $1.80^{\mathrm{e}} \pm 0.05$ & $0.47^{d} \pm 0.00$ \\
\hline NC9 & $4.63^{c} \pm 0.12$ & $0.84^{\mathrm{c}, \mathrm{d}} \pm 0.00$ \\
\hline NB10 & $2.35^{\mathrm{e}} \pm 0.32$ & $1.01^{\mathrm{c}, \mathrm{d}} \pm 0.19$ \\
\hline NC11 & $1.95^{\mathrm{e}} \pm 0.04$ & $0.44^{\mathrm{d}} \pm 0.10$ \\
\hline NB11 & $1.88^{\mathrm{e}} \pm 0.07$ & $1.87^{\mathrm{a}, \mathrm{b}} \pm 0.34$ \\
\hline N20c & $5.92^{b} \pm 0.46$ & $1.24^{b, c} \pm 0.30$ \\
\hline N27d & $3.61^{d} \pm 0.21$ & $0.73^{\mathrm{c}, \mathrm{d}} \pm 0.00$ \\
\hline N29d & $1.94^{\mathrm{e}} \pm 0.08$ & $0.60^{\mathrm{c}, \mathrm{d}} \pm 0.00$ \\
\hline
\end{tabular}

S.E. is standard error of the mean. Means with the same letter are not significantly different at $p \geq 0.05$ within columns using Tukey's test.

Phosphorus $(\mathrm{P})$ is one of the most limited but important plant growth nutrients. It mainly occurs in insoluble forms, whereby phosphate-solubilizing rhizobacteria play a crucial role in converting $\mathrm{P}$ to available forms [54]. Among the eight phosphate-solubilizing strains, PB3 and PB5 showed superior phosphate-solubilization efficiency values in the plate assays (4.21 and 4.10, respectively), whereas, in the enzymatic assays, the highest activity was demonstrated by isolate PC8 (307.7 $\mu \mathrm{g} \mathrm{mL}^{-1}$ ) (Table 3). 
The amount of phosphate-solubilization efficiency and activities with the final broth culture $\mathrm{pH}$ reported in this study is comparable to the range reported elsewhere by Pandey et al. [55], Gulati et al. [56], and Song et al. [57]. Isolate PC8 showed higher phosphate-solubilization activity $\left(307.67 \mu \mathrm{g} \mathrm{mL}{ }^{-1}\right)$ as compared with Pseudomonas putida (B0) at the maximum activity of $247 \mu \mathrm{g} \mathrm{mL}^{-1}$ [55].

Table 3. Phosphate-solubilization efficiency and quantitative phosphate-solubilization estimation based on soluble P by phosphate-solubilizing isolates.

\begin{tabular}{cccc}
\hline Isolate & $\begin{array}{c}\text { Phosphate-solubilizing } \\
\text { Efficiency }\end{array}$ & $\begin{array}{c}\text { Quantitative Phosphate-Solubilization } \\
\text { (Soluble P in } \boldsymbol{\mu g} \mathbf{~ m L}^{-\mathbf{1}} \text { ) }\end{array}$ & $\begin{array}{c}\text { Final Mean } \mathbf{~ H ~ i n ~} \\
\text { Broth Culture }\end{array}$ \\
\hline & Mean Value \pm S.E. & \\
\hline PB5 & $4.21^{\mathrm{a}} \pm 0.22$ & $96.00^{\mathrm{d}} \pm 2.65$ & 4.27 \\
PC1 & $2.38^{\mathrm{c}, \mathrm{d}} \pm 0.15$ & $9.14^{\mathrm{f}} \pm 0.75$ & 4.93 \\
PB7 & $3.18^{\mathrm{b}} \pm 0.23$ & $159.00^{\mathrm{c}} \pm 1.53$ & 4.15 \\
PB3 & $4.10^{\mathrm{a}} \pm 0.23$ & $209.17^{\mathrm{b}} \pm 8.97$ & 4.11 \\
PC6 & $1.85^{\mathrm{e}, \mathrm{f}} \pm 0.05$ & $31.53^{\mathrm{e}} \pm 0.39$ & 4.63 \\
PC8 & $2.74^{\mathrm{b}, \mathrm{c}} \pm 0.22$ & $307.67^{\mathrm{a}} \pm 8.41$ & 4.04 \\
PB11 & $1.66^{\mathrm{f}} \pm 0.08$ & $3.25^{\mathrm{f}} \pm 0.52$ & 4.57 \\
PB6 & $2.19^{\mathrm{d}, \mathrm{e}} \pm 0.24$ & $12.67^{\mathrm{f}} \pm 0.55$ & 4.20 \\
\hline
\end{tabular}

S.E. is standard error of the mean. Means with the same letter are not significantly different at $p \geq 0.05$ within columns using Tukey's test.

There was no significant relationship between phosphate-solubilizing efficiency and soluble phosphate. Similar observations had been previously reported by Nautiyal [32] and Chang and Yang [58]. Nautiyal [32] reported the inability of phosphate-solubilizing Pseudomonas aerogenes and Pseudomonas sp.1 to produce haloes on solid media while still being able to solubilize substantial amounts of $\mathrm{P}$ in different types of broth cultures. Nonetheless, there was a significant inverse correlation $(\mathrm{r}=-0.74, p \leq 0.05)$ between soluble phosphate and the $\mathrm{pH}$ of the culture broth, and this observation corroborates previous findings $[59,60]$. The $\mathrm{pH}$ of the broth declined to a low of 4.04 , as observed in PC8 activity, from the initial $\mathrm{pH}$ 7. This observation is consistent with earlier findings where there was a drop in $\mathrm{pH}$ due to bacterial activity accompanied by mineral phosphate-solubilization and increase in activity efficiency [55].

\subsection{Cultural, Biochemical and Molecular Identification of Selected Functional Bacterial Isolates}

The isolation of bacteria near the root zones of vegetation thriving in the rehabilitated forest generally leads to the recovery of putative beneficial rhizospheric or even free-living functional bacteria. In this study, growth in the selective media proved to be a successful strategy to select bacteria based on their phenotypic activities on the respective media. Among the isolates assessed for their functional activities, five isolates of each functional group were selected to be further characterized on the basis of these distinct colony morphology and high functional activities. After being selected based on these combined criteria, the isolates were grouped by morphological similarities and phenotypic characteristics.

Based on the morphological characteristics of the 15 selected isolates shown in Appendix A, Table A1, they exhibited varying properties. It was observed that the majority or 13 isolates exhibited round colonies in configuration or form; 10 colonies were convex while the rest showed raised elevations; 14 colonies were opaque in density; colonies of all the isolates were almost creamy or yellowish in color; 13 showed Gram negative reactions; all isolates were rods or short rods in single or in pair arrangements; 13 were without endospore production; and they were mostly motile, as exhibited by 11 isolates. Additionally, the following morphological properties presented more diverse characteristics: colony margin was represented by eight entires, three undulates and serrates, respectively, and one lobate; colony size was represented by six moderates, five smalls, three large, and one pinpoint; and the shapes of the endospores produced by two isolates were rods and coccus, respectively. 
The isolates were primarily identified based on the molecular method, and in cases of multiple identities produced based on the BLAST generated database, morphological (Appendix A, Table A1), and biochemical (Appendix A, Table A2) properties facilitated downsizing of the identification task. The selected cellulolytic isolates in this study were identified as Serratia nematodiphila strain SP6 (C46d), Serratia marcescens subspecies sakuensis isolate PSB23 (C22b), Stenotrophomonas maltophilia strain KNUC605 (C29b), Bacillus thuringiensis (CB15) and Stenotrophomonas sp. Ellin162 (C41d). The $\mathrm{N}$-fixing isolates consisted of Burkholderia nodosa strain Br3470 (NB1), Delftia lacustris strain 332 (NC9), Stenotrophomonas sp. strain SeaH-As3w (N27d), Ralstonia sp. strain MCT1 (NB10) and Cupriavidus basilensis strain CCUG 49340T (NB11). The phosphate-solubilizing isolates were represented by Burkholderia cepacia strain 5.5B (PB5), Burkholderia cepacia strain ATCC 35,254 (PB3), Burkholderia uboniae (PB7), Burkholderia cepacia strain 2EJ5 (PC8) and Gluconacetobacter diazotrophicus PAl 5 (PB6).

These identities were matched with BLAST databases with the range of $97 \%$ to $100 \%$ base sequence similarities (Table 4). It was observed that identification of bacterial isolates over the three phenotypic groups revealed the predominance of Gram-negative over Gram- positive bacteria in the rehabilitated forest soils.

Table 4. Identities of cellulolytic, nitrogen-fixing, phosphate-solubilizing bacterial isolates based on $16 \mathrm{~S}$ rDNA analysis and the BLAST databases.

\begin{tabular}{|c|c|c|c|c|}
\hline Phenotype & Isolate & Closest Identity & Similarity (\%) & Accession No. \\
\hline \multirow{5}{*}{ Cellulolytic } & C46d & Serratia nematodiphila strain SP6 & $98(324 / 329)$ & JN315887.1 \\
\hline & $\mathrm{C} 22 \mathrm{~b}$ & $\begin{array}{c}\text { Serratia marcescens subspecies sakuensis } \\
\text { isolate PSB23 }\end{array}$ & $97(578 / 594)$ & HQ242736.1 \\
\hline & $\mathrm{C} 29 \mathrm{~b}$ & $\begin{array}{c}\text { Stenotrophomonas maltophilia strain } \\
\text { KNUC605 }\end{array}$ & $99(945 / 949)$ & HМ047520.1 \\
\hline & CB15 & Bacillus thuringiensis & $99(1018 / 1021)$ & FR846529.1 \\
\hline & C41d & Stenotrophomonas sp. Ellin162 & $100(989 / 989)$ & AF409004.1 \\
\hline \multirow{5}{*}{ N-fixing } & NB1 & Burkholderia nodosa strain Br3470 & $98(943 / 967)$ & AM284972.1 \\
\hline & NC9 & Delftia lacustris strain 332 & $99(1009 / 1014)$ & EU888308.1 \\
\hline & N27d & Stenotrophomonas sp. SeaH-As3w & $100(1029 / 1029)$ & FJ607350.1 \\
\hline & NB10 & Ralstonia sp. MCT1 & $99(999 / 1007)$ & DQ232889.1 \\
\hline & NB11 & Cupriavidus basilensis strain CCUG 49340T & $99(961 / 969)$ & FN597608.1 \\
\hline \multirow{5}{*}{$\begin{array}{l}\text { Phosphate- } \\
\text { solubilizing }\end{array}$} & PB5 & Burkholderia cepacia strain 5.5B & $99(874 / 885)$ & FJ652617.1 \\
\hline & PB3 & Burkholderia cepacia strain ATCC 35254 & $99(990 / 993)$ & AY741346.1 \\
\hline & PB7 & Burkholderia uboniae & $99(993 / 997)$ & AB030584.1 \\
\hline & PC8 & Burkholderia cepacia strain 2EJ5 & $99(1008 / 1016)$ & GQ383907.1 \\
\hline & PB6 & Gluconacetobacter diazotrophicus PAl 5 & $97(778 / 801)$ & СР001189.1 \\
\hline
\end{tabular}

The Gram-positive bacteria belonged to only one taxonomic grouping, Firmicutes, represented by the genus Bacillus, whereas the Gram-negative bacteria included Alpha-Proteobacteria with the genus Gluconacetobacter; Beta-Proteobacteria is represented by the genera Burkholderia, Delftia, Ralstonia, and/or Cupriavidus; and Gamma-Proteobacteria is represented by the genera Serratia and Stenotrophomonas.

From the overall identification results for each functional group of isolates, bacteria from genus Burkholderia seemed to predominate in the tropical forest soils with one third of total identified isolates, with distinguishing phosphate-solubilizing and $\mathrm{N}$-fixing capabilities over other genera. The Stenotrophomonas genus ranked second in abundance to Burkholderia. The Burkholderia genus is a well-known classification of bacteria, wherein its members possess vast versatility in niches and nutrition regulation, such as $\mathrm{N}$-fixing and phosphate-solubilization, as well as possessing numerous PGP attributes. Burkholderia species occur in the natural environment, even though some strains are also found in clinical samples, especially the B. cepacia complex (Bcc) species from patients with cystic fibrosis [61].

Based on our 16S rDNA sequence analysis results, the top four isolates with the highest phosphate-solubilizing and N-fixing activities belong to the genus Burkholderia, in which three of them were closely related to B. cepacia ( $99 \%$ similarity) and B. nodosa ( $98 \%$ similarity), respectively. Serratia marcescens (of close similarity by C22b at $97 \%$ ) or Serratia sp. (with C46d closely matched to Serratia 
nematodiphila by $98 \%$ ) are known to have both cellulolytic and phosphate-solubilizing abilities [62,63]. Similar to the results of this study, Stenotrophomonas spp. have been previously reported to possess both N-fixing [64] and cellulose-hydrolyzing abilities [65]. Stenotrophomonas species commonly prevail in nature, whereby S. maltophilia and S. rhizophila are reported to occur as rhizospheric and endophytic bacteria accountable for beneficial plant interactions [65]. The N-fixing isolates in this study displayed higher diversity in terms of species, as well as activities.

Diazotrophic isolate N27d revealed a 100\% matching identity with Stenotrophomonas sp. (strain SeaH-As3w) and it is believed to have cellolulytic potential similar to the C41d and C29b isolates. Previously, many studies have reported bacteria belonging to the genus Burkholderia, especially B. cepacia strains, as having biocontrol ability against many phyto-pathogenic fungi, such as Fusarium sp., Pythium aphanidermatum, Pythium ultimum, Phytophthora capsici, Aspergillus flavus, Botrytis cinerea and Rhizoctonia solani [66-70], as part of its main contributing PGP factors.

The phosphate-solubilizing bacteria showed the lowest diversity with only three species' identities from two genera recorded among the five identified isolates. Isolates PB3, PB5, PB7, and PC8 were closely matched (99\% similarity) to Burkholderia sp. These isolates together with the N-fixing NB1 might potentially possess both N-fixing and phosphate-solubilizing activities [71,72]. All Burkholderia strains in this study demonstrated variability in cultural and biochemical properties, which is typical for members of this genus.

The ability of Burkholderia strains to solubilize inorganic phosphates has been well documented by various studies [73-76], a beneficial property in plant growth promotion. Among the Burkholderia strains isolated in this study, this trait seemed most prevalent. A few Burkholderia strains are known for other PGP abilities, such as the ability to fix $\mathrm{N}_{2}$, either as free-living bacteria [77], or even nodulating ones that also fix $\mathrm{N}_{2}$ on media, including the Burkholderia nodosa strain, as reported by da Silva et al. [78].

The genus Delftia (with close similarity of NC9 to Delftia lacustris at 99\%) belongs to a newly grouped genus closely linked to Comamonas [79]. One of the diazotrophic bacterium IHB B 4037, which displayed closely matched identity with Delftia lacustris isolated from the rhizosphere of tea plants in India, showed the highest nitrogenase activity in a study conducted by Gulati et al. [80]. Delftia tsuruhatensis was also revealed to be a diazotroph with biological control ability against several plant pathogens, especially the three main rice pathogens: the likes of Xanthomonas oryzae pv. Oryzae, Rhizoctonia solani, and Pyricularia oryzae Cavara [81]. In summary, the variability among the bacterial strains of the same genera pointed to the fact that bacterial phenotypic properties are influenced by genetic factors, as well as environmental factors [82].

\subsection{Seed Germination and Shoot and Root Elongation Assays}

Seed germination and shoot and root elongation assays were done on 15 selected functional isolates on Green Gram seeds (Table 5) to represent an attribute of early plant growth promotion activity by the isolates.

After a week of growth, Green Gram roots originating from seeds treated with all selected bacterial strains exhibited different effects on root lengths, shoot lengths, and seedling vigor indexes compared with the two controls, treated with distilled water and nutrient broth, respectively. As shown in Table 5, inoculation with cellulolytic isolate C41d (Stenotrophomonas sp.) resulted in significantly longer root lengths compared to both control treatments but was not significantly different from the rest of the cellulolytic isolates. On the other hand, the treatments with all selected cellulolytic strains resulted in significantly higher shoot lengths compared to both controls but were not different from one another, ranging from 11.46 to $12.9 \mathrm{~cm}$. In terms of the seedling vigor index (SVI), all cellulolytic strains exhibited significantly higher values, at least $33.6 \%$ to $42.7 \%$ higher than both controls, with isolate C22b (Serratia marcescens subsp. sakuensis) showing outstanding values but not different from isolates CB15, C41d, and C46d (Bt, Stenotrophomonas sp., and Serratia nematodiphila), which ranged from 1670 to 1815 . 
Table 5. Effects of selected cellulolytic, N-Fixing, phosphate-solubilizing bacterial inoculation on the early growth stage of green gram.

\begin{tabular}{|c|c|c|c|c|c|c|}
\hline Treatment & $\begin{array}{c}\text { Mean Number of } \\
\text { Seed Germinated } \\
\text { (3rd day) }\end{array}$ & $\begin{array}{c}\text { Mean Number of } \\
\text { Seed Germinated } \\
\text { (7th day) }\end{array}$ & $\begin{array}{c}\text { Mean Length of } \\
\text { Shoots }(\mathrm{cm}) \\
\text { (Mean } \pm \text { S.E.) }\end{array}$ & $\begin{array}{c}\text { Mean Length of } \\
\text { Radicle }(\mathrm{cm}) \\
\text { (Mean } \pm \text { S.E.) }\end{array}$ & $\begin{array}{c}\% \text { Germinated } \\
\text { Seeds }\end{array}$ & $\begin{array}{l}\text { Vigor index } \\
(\text { Mean } \pm \text { S.E.) }\end{array}$ \\
\hline \multicolumn{7}{|c|}{ Cellulolytic } \\
\hline $\mathrm{C} 22 \mathrm{~b}$ & 50.0 & 50.0 & $12.84^{\mathrm{a}} \pm 0.06$ & $5.16^{\mathrm{a}, \mathrm{b}} \pm 0.04$ & 100 & $1799.50^{\mathrm{a}} \pm 2.50$ \\
\hline CB15 & 50.0 & 50.0 & $12.38^{\mathrm{a}} \pm 0.45$ & $5.47^{\mathrm{a}, \mathrm{b}} \pm 0.75$ & 100 & $1785.00^{\mathrm{a}, \mathrm{b}} \pm 30.00$ \\
\hline C41d & 50.0 & 50.0 & $11.75^{\mathrm{a}} \pm 0.03$ & $5.67^{\mathrm{a}} \pm 0.13$ & 100 & $1741.50^{\mathrm{a}, \mathrm{b}} \pm 10.50$ \\
\hline C46d & 50.0 & 50.0 & $11.73^{\mathrm{a}} \pm 0.23$ & $5.28^{\mathrm{a}, \mathrm{b}} \pm 0.53$ & 100 & $1700.00^{\mathrm{a}, \mathrm{b}} \pm 30.00$ \\
\hline $\mathrm{C} 29 \mathrm{~b}$ & 50.0 & 50.0 & $11.81^{\mathrm{a}} \pm 0.35$ & $5.04^{\mathrm{a}, \mathrm{b}} \pm 0.40$ & 100 & $1684.50^{b} \pm 5.50$ \\
\hline Control (Nutrient broth) & 50.0 & 50.0 & $9.26^{b} \pm 0.18$ & $3.36^{b, c} \pm 0.02$ & 100 & $1261.00^{c} \pm 19.00$ \\
\hline Control $\left(\mathrm{dH}_{2} \mathrm{O}\right)$ & 49.5 & 49.5 & $7.91^{b} \pm 0.18$ & $2.87^{c} \pm 0.10$ & 99 & $1067.00^{\mathrm{d}} \pm 17.00$ \\
\hline \multicolumn{7}{|c|}{ N-fixing } \\
\hline NB1 & 50.0 & 50.0 & $11.27^{\mathrm{a}} \pm 0.06$ & $3.84^{\mathrm{a}, \mathrm{b}} \pm 0.02$ & 100 & $1510.00^{\mathrm{a}} \pm 4.00$ \\
\hline NC9 & 50.0 & 50.0 & $11.00^{\mathrm{a}} \pm 0.32$ & $4.10^{\mathrm{a}} \pm 0.34$ & 100 & $1510.00^{\mathrm{a}} \pm 66.00$ \\
\hline NB10 & 50.0 & 50.0 & $10.81^{\mathrm{a}, \mathrm{b}} \pm 0.15$ & $3.89^{\mathrm{a}, \mathrm{b}} \pm 0.24$ & 100 & $1469.00^{\mathrm{a}} \pm 9.00$ \\
\hline NB11 & 50.0 & 50.0 & $10.43^{a, b} \pm 0.27$ & $4.09^{a} \pm 0.26$ & 100 & $1451.50^{\mathrm{a}, \mathrm{b}} \pm 52.50$ \\
\hline N27d & 50.0 & 50.0 & $10.31^{\mathrm{a}, \mathrm{b}} \pm 0.61$ & $3.68^{\mathrm{a}, \mathrm{b}} \pm 0.19$ & 100 & $1399.00^{\mathrm{a}, \mathrm{b}} \pm 42.00$ \\
\hline Control (Nutrient broth) & 50.0 & 50.0 & $9.26^{b c} \pm 0.18$ & $3.36^{\mathrm{a}, \mathrm{b}} \pm 0.02$ & 100 & $1261.00^{b, c} \pm 19.00$ \\
\hline Control $\left(\mathrm{dH}_{2} \mathrm{O}\right)$ & 49.5 & 49.5 & $7.91^{\mathrm{c}} \pm 0.18$ & $2.87^{b} \pm 0.10$ & 99 & $1067.00^{c} \pm 17.00$ \\
\hline \multicolumn{7}{|c|}{ Phosphate-solubilizing } \\
\hline PB3 & 50.0 & 50.0 & $12.25^{\mathrm{a}} \pm 0.08$ & $5.14^{a} \pm 0.02$ & 100 & $1738.50^{a} \pm 9.50$ \\
\hline PB7 & 50.0 & 50.0 & $12.08^{\mathrm{a}, \mathrm{b}} \pm 0.40$ & $4.89^{\mathrm{a}, \mathrm{b}} \pm 0.33$ & 100 & $1696.00^{\mathrm{a}, \mathrm{b}} \pm 7.00$ \\
\hline PB5 & 50.0 & 50.0 & $11.78^{\mathrm{a}, \mathrm{b}, \mathrm{c}} \pm 0.21$ & $4.61^{\mathrm{a}, \mathrm{b}} \pm 0.35$ & 100 & $1638.50^{\mathrm{b}} \pm 14.50$ \\
\hline PB6 & 50.0 & 50.0 & $10.97^{b, c} \pm 0.06$ & $4.18^{\mathrm{a}, \mathrm{b}, \mathrm{c}} \pm 0.31$ & 100 & $1514.50^{\mathrm{c}} \pm 25.50$ \\
\hline PC8 & 50.0 & 50.0 & $10.71^{\mathrm{c}} \pm 0.18$ & $3.73^{b, c, d} \pm 0.04$ & 100 & $1443.00^{c} \pm 14.00$ \\
\hline Control (Nutrient broth) & 50.0 & 50.0 & $9.26^{\mathrm{d}} \pm 0.18$ & $3.36^{\mathrm{c}, \mathrm{d}} \pm 0.02$ & 100 & $1261.00^{d} \pm 19.00$ \\
\hline Control $\left(\mathrm{dH}_{2} \mathrm{O}\right)$ & 49.5 & 49.5 & $7.91^{\mathrm{e}} \pm 0.18$ & $2.87^{\mathrm{d}} \pm 0.10$ & 99 & $1067.00^{\mathrm{e}} \pm 17.00$ \\
\hline
\end{tabular}

Data are presented as mean \pm standard error (S.E.) of the duplicates of 50 seedlings for each replicate per treatment for root elongation assay and seedling vigor index. The roots emerging from seeds failing to germinate after two days were previously marked and were not measured. The seedling vigor index (SVI) was calculated using the formula: SVI $=\%$ of germination $x$ seedling length (root length + shoot length). In the same column, significant differences according to Tukey's test at the $p \leq 0.05$ level are indicated by different letters. 
The treatments with N-fixing isolates NC9 (Delftia lacustris) and NB11 (Cupriavidus basilensis) showed higher root lengths and shoot lengths occurring in the range of $3.76 \mathrm{~cm}$ to $4.44 \mathrm{~cm}$ and $10.68 \mathrm{~cm}$ to $11.33 \mathrm{~cm}$, respectively, whereas the SVI values for isolates NB1, NC9, and NB10 (Burkholderia nodosa, Delftia lacustris and Ralstonia sp.) revealed significantly higher SVI values than both controls, ranging from 1444 to 1576 , that is, at least $16.5 \%$ to $19.8 \%$ higher but not significantly different from the rest of the N-fixing strains (Table 5).

All the five selected phosphate-solubilizing isolates resulted in significantly higher SVI values than both controls by at least $14.4 \%$ to $37.9 \%$, that is, in the range of 1429 to 1748 . Isolates PB3, PB5, and PB7 (Burkholderia cepacia, Burkholderia cepacia, and Burkholderia uboniae) resulted in the longest root lengths among the phosphate-solubilizing strains in the range of 4.26 to $5.16 \mathrm{~cm}$. However, significantly higher shoot lengths were achieved with phosphate-solubilizing isolates than both controls, ranging from 10.53 to $12.33 \mathrm{~cm}$. Isolate PB3 had the most outstanding effect on shoot length, but was not different from that of isolates PB5 and PB7, among the other PSB strains. (Table 5).

A previous study by Satya et al. [83] resulted in similar observations for Burkholderia sp. as their application using Burkholderia sp. strain TNAU-1 demonstrated improvement in root and shoot lengths, as well as increased seedling vigour in mung beans. According to Egamberdieva et al. [84], the inoculation of one of the salt tolerant rhizobacterial strains, Stenotrophomonas rhizophila ep-17, resulted in the improved dry weight of cucumber by up to $68 \%$ in various salt concentrations as high as $10 \mathrm{dSm}^{-1}$ in comparison to non-inoculated plants exposed to salt stress.

Hameeda et al. [85] demonstrated that one of the phosphate-solubilizing bacterial strains in their study, Serratia marcescens, designated as EB 67, which was tested on maize growth by the paper towel method, was able to produce higher root and plumule lengths, plant weight (43\%), and seed vigor index, whereas another strain also included in the study, Serratia sp., designated as EB75, resulted in increased root length, plant weight by $23 \%$, and seed vigor index over that of the uninoculated control.

Kang et al. [86] reported that the inoculation of a novel cold stress resistant rhizobacteria Serratia nematodiphila PEJ1011 on pepper plants resulted in the latter's significantly improved growth in terms of both increased root and shoot lengths and fresh weight of the peppers in both normal and cold temperatures as compared with controls under normal and cold temperature, respectively. Apart from Bacillus thuringiensis (Bt), which has been reported as having apparent biological control attributes, a study by Khan et al. [87] also reported plant growth-promotion via an increase in the plant growth parameters of mung bean seeds coated with various Bt strains used in their study. Apart from having high nitrogenase activity strains from rhizospheric soil of tea plants $[80,88]$, Delftia lacustris isolated from rhizospheric soils of tobacco was found to be a strongly antagonistic bacteria against the pathogen Phytophthora nicotianae, which could have potentially helped in promoting growth of the tobacco crop.

Cupriavidus (synonym Ralstonia) is closely linked to Burkholderia, but, compared to the latter genus, it consists of very limited N-fixing species [89]. Both genera, Burkholderia spp. and Cupriavidus taiwanensis, have been reported to be N-fixing symbionts of legume Mimosa with the ability to nodulate the latter [90-92].

Burkholderia nodosa designated as LMG 23,741 has also been isolated from acidic soils of the Amazon as a nodulating N-fixing bacteria [78], as compared to the strain in this study that did not nodulate but was a free-living or rhizospheric $\mathrm{N}$ fixer. Both strains are known to be unable to solubilize inorganic phosphates. The strain reported by da Silva et al. [78] also did not possess anti-fungal characteristics. Besides the N-fixing isolate Ralstonia sp. characterized in this study, Ralstonia taiwanensis is the first N-fixing beta-proteobacterium strain with the ability to nodulate the roots of Mimosa from which it was isolated [93].

Burkholderia cepacia designated as LMG 1222 by da Silva et al. [78] was also reported as a non-N-fixing bacteria isolated from acidic Amazon soils that could solubilize inorganic phosphates, in addition to possessing anti-fungal properties. However, the literature is lacking on the beneficial properties of Burkholderia uboniae, and, hence, the results of this study could contribute to the primary evaluation on the potential of this particular strain on early plant growth promotion. Cupriavidus 
basilensis designated HMF14 has also been recently identified as an important furan-degrading bacterium and was isolated by employing an elegant assay based on the germination of lettuce seeds [94].

Gluconacetobacter diazotrophicus is one of the diazotrophic species reported to form anomalous symbiotic relationships with plants by thriving on the root system surface as rhizobacteria, whereas a number of strains are known to infect plant tissues as endophytic bacteria and to fix $\mathrm{N}_{2}$, resulting in enhanced plant growth [95-98].

\subsection{Indole-3-Acetic Acid Assay}

Out of the 15 previously selected functional bacterial isolates for the IAA assay, only seven isolates produced IAA, as shown in Table 6.

Table 6. Indole-3-acetic acid production by selected functional bacterial isolates.

\begin{tabular}{ccc}
\hline Phenotype & Isolate & $\begin{array}{c}\text { IAA Production }\left(\boldsymbol{\mu g} \mathbf{~ m L}^{-\mathbf{1}}\right) \\
\text { Mean } \pm \text { S.E. }\end{array}$ \\
\hline \multirow{2}{*}{ Cellulolytic } & Stenotrophomonas maltophilia C29b & $12.38^{\mathrm{a}} \pm 1.48$ \\
& Serratia nematodiphila C46d & $11.39^{\mathrm{a}, \mathrm{b}} \pm 1.68$ \\
& Bacillus thuringiensis CB15 & $0.98^{\mathrm{c}} \pm 0.16$ \\
\hline \multirow{2}{*}{ Phosphate-solubilizing } & Burkholderia cepacia PC8 $8.45^{\mathrm{a}, \mathrm{b}} \pm 0.28$ \\
& Burkholderia cepacia PB3 & $7.81^{\mathrm{b}} \pm 0.11$ \\
\hline Nitrogen-fixing & Gluconacetobacter diazotrophicus PB6 & $7.51^{\mathrm{b}} \pm 0.17$ \\
\hline
\end{tabular}

S.E. is the standard error of the mean value. Significant differences according to Tukey's test at $p \leq 0.05$ level are indicated by different letters.

All the seven selected strains produced IAA without supplementation of L-tryptophan, from $\mathrm{N}$-fixing isolate Burkholderia nodosa NB1 to the most abundant IAA production by cellulolytic isolates Stenotrophomonas maltophilia $\mathrm{C} 29 \mathrm{~b}$ and Serratia nematodiphila C46d, and phosphate-solubilizing isolate Burkholderia cepacia PC8, ranging from 8.17 to $13.86 \mu \mathrm{g} \mathrm{mL}{ }^{-1}$. The IAA produced by the cellulolytic, non-N-fixing Stenotrophomonas maltophilia strain in this study, $\mathrm{C} 29 \mathrm{~b}$, was $12.38 \mu \mathrm{g} \mathrm{mL}^{-1}$, in the absence of tryptophan. Stenotrophomonas maltophilia has been previously reported as being diazotrophic with IAA production of $2.6 \mathrm{mg} \mathrm{mL}^{-1}$ [99], $112.8 \mu \mathrm{g} \mathrm{mL}{ }^{-1}$ for S. maltophilia PM-1, and $139.2 \mu \mathrm{g} \mathrm{mL}^{-1}$ in S. maltophilia PM-26 [100] with L-tryptophan as a supplement.

The Serratia nematodiphila C46d strain in this study was found to synthesize IAA, as well as solubilize phosphate at $11.39 \mu \mathrm{g} \mathrm{mL}^{-1}$ and $14.25 \mu \mathrm{g} \mathrm{mL} \mathrm{m}^{-1}$, respectively. In comparison, Serratia nematodiphila NII-0928 isolated from Western ghat forest soil was also found to possess multiple PGP attributes, including phosphate-solubilization, and IAA production at higher concentrations, with values of $76.6 \mu \mathrm{g} \mathrm{mL}^{-1}$ and $58.9 \mu \mathrm{g} \mathrm{mL}^{-1}$, respectively [101]. As stated previously, the variability of the bacterial strains of the same genera points to the fact that bacterial phenotypic properties are influenced by genetic and environmental factors [82]. The Bacillus thuringiensis strain CB15 in this study yielded IAA quantities within the range of 0.12 to $6.59 \mu \mathrm{g} \mathrm{mL}^{-1}$, as was reported by Vidal-Quist et al. [102].

Burkholderia cepacia strains PC8 and PB3 evaluated in this study, without the addition of tryptophan, produced IAA quantities of 8.45 and $7.81 \mu \mathrm{g} \mathrm{mL} \mathrm{m}^{-1}$, respectively. Bevivino et al. [103] reported that rhizospheric strains of Burkholderia cepacia PHP7 and TVV75 were found to produce IAA of approximately 0.6 and $0.4 \mu \mathrm{g} \mathrm{mL}{ }^{-1}$, respectively, both of which were far lacking by at least 14-folds, even with the addition of L-tryptophan, in comparison to the strains in this study. This phenomenon could indicate that B. cepacia strains are actively involved in IAA synthesis in pure cultures [104].

The phosphate-solubilizing and non-N-fixing Gluconacetobacter diazotrophicus strain PB6 produced an IAA quantity of $7.51 \mu \mathrm{g} \mathrm{mL} \mathrm{m}^{-1}$ without the precursor tryptophan, which was higher than that reported previously, and improved the shoot length and vigor index of green gram compared 
to that of the uninoculated controls. Anitha and Thangaraju [105] reported an endophytic diazotroph Gluconacetobacter diazotrophicus strain in their study to have exhibited nitrogenase activity, phosphate-solubilization, and IAA production with and without tryptophan, with values of $4.74 \mu \mathrm{g}$ $\mathrm{mL}^{-1}$ and $1.4 \mu \mathrm{g} \mathrm{mL}^{-1}$, respectively. Despite the lesser amount of IAA produced by the Burkholderia nodosa strain NB1 with a value of $0.43 \mu \mathrm{g} \mathrm{mL}^{-1}$, this is the first result on IAA production ever reported for the non-nodulating N-fixing Burkholderia nodosa strain.

The presence of an appropriate precursor such as L-tryptophan may mediate the production of auxins by some microorganisms [106]. The influence of auxins on plant seedlings depends on their concentrations. For instance, high concentrations may suppress growth, whereas low concentrations may produce stimulative effects on growth [107]. The absence of tryptophan precursor in IAA production has also been previously observed in other bacterium, such as Azotobacter brasilense, in a mechanism known as a tryptophan-independent pathway, which was suggested during experiments using labelled tryptophan [108].

According to Spaepen and Vanderleyden [109], the occurrence of some IAA production, despite the inactivation of every pathway, in some studies revealed the redundancy of IAA biosynthetic pathways in some of the studied microorganisms, indicating that several pathways do exist and are active in a single microorganism. Nevertheless, the ability to secrete IAA without absolute dependence on tryptophan as the main precursor proved to be an added advantage over tryptophan dependent microbes in plant rhizospheres to produce beneficial associative effects on plant roots to enhance plant growth.

\section{Conclusions}

The results of this study reveal the presence of some efficient and beneficial cellulolytic, N-fixing, phosphate-solubilizing bacterial species among the natural rhizo-bacterial community in soils of a tropical rehabilitated forest at Universiti Putra Malaysia Bintulu Campus, Malaysia. Out of the 15 identified bacterial isolates possessing beneficial phenotypic traits, a third belong to the genus Burkholderia and a fifth belong to Stenotrophomonas sp., with both genera consisting of members from two different functional groups. The results of the experiments also confirm the multiple PGP traits of the selected bacterial isolates based on their respective functional activities, root and shoot lengths, and seedling vigour improvements when bacterized on mung bean seeds, as well as significant IAA production. Some of the results were comparable, if not better in some cases, to those of related studies. All these functional bacterial strains could potentially produce beneficial synergistic effects via their versatile properties to improve soil fertility and possible plant growth stimulation through beneficial interactions.

Author Contributions: A.T., A.O.H., N.M.A.M. and M.B.J. conceived and designed the experiments, contributed regents, materials and analysis tools, were involved in the preparation of the manuscript and making the decision to publish. A.T., A.O.H. and M.B.J. were also involved in data collection and analysis. All authors have read and agreed to the published version of the manuscript.

Funding: This research was funded by Ministry of Higher Education, Malaysia and Universiti Putra Malaysia.

Acknowledgments: The authors are grateful to colleagues and staff of Universiti Putra Malaysia Bintulu Sarawak Campus, Department of Agriculture, Kuching, Sarawak for the technical cooperation and also Mitsubishi Corporation.

Conflicts of Interest: The authors declare no conflict of interest. 


\section{Appendix A}

Table A1. Morphological characteristics of selected functional isolates.

\begin{tabular}{|c|c|c|c|c|c|c|c|c|c|c|c|c|c|c|c|}
\hline \multirow{2}{*}{ Colony Morphology } & \multicolumn{15}{|c|}{ Isolate } \\
\hline & CB15 & C22d & C29b & C41d & C46d & NB1 & NB10 & NB11 & N27d & NC9 & PB3 & PB5 & PB6 & PB7 & PC8 \\
\hline Configuration/Form & Irregular & Round & Round & Irregular & Round & Round & Round & Round & Round & Round & Round & Round & Round & Round & Round \\
\hline Margin & Undulate & Entire & Entire & Serrate & Entire & Entire & Undulate & Undulate & Entire & Entire & Entire & Serrate & Serrate & Entire & Lobate \\
\hline Elevation & Raised & Convex & Convex & Raised & Convex & Convex & Raised & Convex & Convex & Convex & Convex & Raised & Raised & Convex & Convex \\
\hline Density & Opaque & Opaque & Opaque & Opaque & Opaque & Opaque & Opaque & Opaque & Opaque & Opaque & Opaque & Opaque & Transparent & Opaque & Opaque \\
\hline Pigments & Cream & Cream & Yellow & Cream & Cream & Cream & Cream & Cream & $\begin{array}{l}\text { Yellowish } \\
\text { cream }\end{array}$ & Cream & $\begin{array}{l}\text { Yellowish } \\
\text { cream }\end{array}$ & Cream & Cream & Cream & Cream \\
\hline Gram's reaction & + & - & - & - & - & - & - & - & - & - & - & - & + & - & - \\
\hline Shape & Rods & Rods & Rods & Short rods & Short rods & Short rods & Short rods & Rods & Short rods & Short rods & Rods & Rods & Short rods & Rods & Short rods \\
\hline Size & Large & Moderate & Small & Large & Small & Pinpoint & Large & Moderate & Small & Moderate & Moderate & Moderate & Moderate & Small & Small \\
\hline Arrangement & Single & Single & Single/pairs & Single & Single & Single & Single & Single & Single & Single/pairs & Single & Single/pairs & Single/pairs & Single/pairs & Single/pairs \\
\hline Endospore production & + & - & - & - & - & - & - & - & + & - & - & - & - & - & - \\
\hline Endospore shape & Rods & - & - & - & - & - & - & - & Coccus & - & - & - & - & - & - \\
\hline Motility & + & + & + & - & + & - & + & - & - & + & + & + & + & + & + \\
\hline
\end{tabular}


Table A2. Biochemical properties of selected functional bacterial isolates.

\begin{tabular}{|c|c|c|c|c|c|c|c|c|c|c|}
\hline Isolate & Catalase & MCA & KIA & SA & SCA & SMA & T80A & NG & Indole & NRT \\
\hline CB15 & + & - & Glu ferm +, Lacferm - & - & - & + & + & + & - & + \\
\hline $\mathrm{C} 22 \mathrm{~d}$ & + & + & Glu ferm +, Lacferm - & - & + & + & + & + & - & + \\
\hline $\mathrm{C} 29 \mathrm{~b}$ & + & + & Glu ferm -, Lacferm - & - & + & + & + & + & - & + \\
\hline C41d & + & - & Glu ferm +, Lacferm - & - & - & + & - & + & - & + \\
\hline C46d & + & + & Glu ferm +, Lacferm - & - & + & + & + & + & - & + \\
\hline NB1 & + & + & Glu ferm -, Lacferm - & - & + & - & + & - & - & + \\
\hline NB10 & + & - & Glu ferm +, Lacferm - & + & + & + & + & + & - & - \\
\hline NB11 & + & - & Glu ferm -, Lacferm + & + & - & - & + & - & - & + \\
\hline N27d & + & + & Glu ferm -, Lacferm - & - & + & + & - & + & - & + \\
\hline NC9 & + & + & Glu ferm +, Lacferm - & - & + & + & + & + & - & + \\
\hline PB3 & + & + & Glu ferm -, Lacferm - & - & + & + & + & + & - & + \\
\hline PB5 & + & - & Glu ferm -, Lacferm - & + & + & + & - & + & - & + \\
\hline PB6 & + & - & Glu ferm -, Lacferm - & + & + & + & - & + & - & + \\
\hline PB7 & + & + & Glu ferm -, Lacferm - & - & + & + & + & + & - & + \\
\hline PC8 & + & + & Glu ferm -, Lacferm - & - & + & + & + & + & - & + \\
\hline
\end{tabular}

Note: +, positive result; -, negative result; MCA: Mac Conkey agar assay; KIA: Kligler Iron Agar assay; Glu ferm, Glucose fermentation; Lacferm, Lactose fermentation; SA: Starch agar assay; SCA: Simmons citrate agar; SMA: Skim milk agar; T80A: Tween 80 Agar assay; NG: Nutrient gelatine assay; Indole: Indole production assay; NRT: Nitrate reduction test assay.

\section{References}

1. Strassburg, B.B.N.; Kelly, A.; Balmford, A.; Davies, R.G.; Gibbs, H.K.; Lovett, A.; Miles, L.; Orme, C.D.L.; Price, J.; Turner, R.K.; et al. Global congruence of carbon storage and biodiversity in terrestrial ecosystems. Conserv. Lett. 2010, 3, 98-105. [CrossRef]

2. Saatchi, S.S.; Harris, N.L.; Brown, S.; Lefsky, M.; Mitchard, E.T.A.; Salas, W.; Zutta, B.R.; Buermann, W.; Lewis, S.L.; Hagen, S.; et al. Benchmark map of forest carbon stocks in tropical regions across three continents. Proc. Natl. Acad. Sci. USA 2011, 108, 9899-9904. [CrossRef] [PubMed]

3. Tropek, R.; Sedláček, O.; Beck, J.; Keil, P.; Musilová, Z.; Šímová, I.; Storch, D. Comment on high-resolution global maps of 21st-century forest cover change. Science 2014, 344, 981. [CrossRef] [PubMed]

4. Lal, R. Soil erosion and the global carbon budget. Environ. Int. 2003, 29, 437-450. [CrossRef]

5. Morgan, R.P.C. Soil Erosion and Conservation, 3rd ed.; Wiley-Blackwell: Oxford, UK, 2005; p. 316.

6. Grainger, A. Controlling Tropical Deforestation, 1st ed.; Earthscan: London, UK, 1993; p. 310.

7. Roesch, L.F.; Fulthorpe, R.R.; Riva, A.; Casella, G.; Hadwin, A.K.M.; Kent, A.D.; Daroub, S.H.; Camargo, F.A.O.; Farmerie, W.G.; Triplett, E.W. Pyrosequencing enumerates and contrasts soil microbial diversity. ISME J. 2007, 1, 283-290. [CrossRef] [PubMed]

8. Bardgett, R.D.; Freeman, C.; Ostle, N.J. Microbial contributions to climate change through carbon cycle feedbacks. ISME J. 2008, 2, 805-814. [CrossRef] [PubMed]

9. Fulthorpe, R.R.; Roesch, L.F.W.; Riva, A.; Triplett, E.W. Distantly sampled soils carry few species in common. ISME J. 2008, 2, 901-910. [CrossRef]

10. Berg, B.; Laskowski, R. Litter decomposition: A guide to carbon and nutrient turnover. In Advances in Ecological Research, 1st ed.; Yiqi, L., Ed.; Academic Press: Amsterdam, The Netherlands, 2005; Volume 38, p. 448.

11. Lynd, L.R.; Weimer, P.J.; van Zyl, W.H.; Pretorious, I.S. Microbial cellulose utilization: Fundamentals and biotechnology. Microbiol. Mol. Biol. Rev. 2002, 66, 506-577. [CrossRef]

12. Baldrian, P.; Valášková, V. Degradation of cellulose by basidiomycetous fungi. FEMS Microbiol. Rev. 2008, 32, 501-521. [CrossRef]

13. Kjoller, A.; Struwe, S. Fungal communities, succession, enzymes, and decomposition. In Enzymes in the Environment: Activity, Ecology and Applications, 1st ed.; Burns, R.G., Dick, R.P., Eds.; Marcel Dekker: New York, NY, USA, 2002; pp. 267-284.

14. de Boer, W.; Folman, L.B.; Summerbell, R.C.; Boddy, L. Living in a fungal world: Impact of fungi on soil bacterial niche development. FEMS Microbiol. Rev. 2005, 2, 795-811. [CrossRef]

15. Ward, N.L.; Challacombe, J.F.; Janssen, P.H.; Henrissat, B.; Coutinho, P.M.; Wu, M.; Xie, G.; Haft, D.H.; Sait, M.; Badger, J.; et al. Three genomes from the phylum Acidobacteria provide insight into the lifestyles of these microorganisms in soils. Appl. Environ. Microbiol. 2009, 75, 2046-2056. [CrossRef] [PubMed] 
16. Pankratov, T.A.; Ivanova, A.O.; Dedysh, S.N.; Liesack, W. Bacterial populations and environmental factors controlling cellulose degradation in an acidic sphagnum peat. Environ. Microbiol. 2011, 13, 1800-1814. [CrossRef] [PubMed]

17. Galloway, J.N.; Townsend, A.R.; Erisman, J.W.; Bekunda, M.; Cai, Z.; Freney, J.R.; Martinelli, L.A.; Seitzinger, S.P.; Sutton, M.A. Transformation of the nitrogen cycle: Recent trends, questions, and potential solutions. Science 2008, 320, 889-892. [CrossRef] [PubMed]

18. Eady, R.R. The dinitrogen-fixing bacteria. In The Prokaryotes, 2nd ed.; Balows, A., Truper, H.G., Dworkin, M., Harder, W., Schleifer, K.H., Eds.; Springer: New York, NY, USA, 1992; pp. 534-553.

19. Young, J.P.W. Phylogenetic classification of nitrogen fixing organisms. In Biological Nitrogen Fixation, 1st ed.; Stacey, G., Burris, R.H., Evans, H.J., Eds.; Chapman and Hall: New York, NY, USA, 1992; pp. 43-86.

20. Cleveland, C.C.; Townsend, A.R.; Schimel, D.S.; Fisher, H.; Howarth, R.W.; Hedin, L.O.; Perakis, S.S.; Latty, E.F.; Von Fischer, J.C.; Elseroad, A.; et al. Global patterns of terrestrial biological nitrogen $\left(\mathrm{N}_{2}\right)$ fixation in natural ecosystems. Global Biogeochem. Cycles. 1999, 13, 623-645. [CrossRef]

21. Rengel, Z.; Marschner, P. Nutrient availability and management in the rhizosphere: Exploiting genotypic differences. New Phytol. 2005, 168, 305-312. [CrossRef]

22. Panhwar, Q.A.; Naher, U.A.; Jusop, S.; Othman, R.; Latif, M.A.; Ismail, M.R. Biochemical and molecular characterization of potential phosphate-solubilizing bacteria in acid sulfate soils and their beneficial effects on rice growth. PLoS ONE 2014, 9, e97241. [CrossRef]

23. Sharma, S.B.; Sayyed, R.Z.; Trivedi, M.H.; Gobi, T.A. Phosphate solubilizing microbes: Sustainable approach for managing phosphorus deficiency in agricultural soils. Springer Plus 2013, 2, 587. [CrossRef]

24. Rodriguez, H.; Fraga, R. Phosphate solubilizing bacteria and their role in plant growth promotion. Biotechnol. Adv. 1999, 17, 319-339. [CrossRef]

25. Janssen, P.H. Identifying the dominant soil bacteria taxa in libraries of 16S rRNA and 16S rRNA genes. Appl. Environ. Microbiol. 2006, 72, 1719-1728. [CrossRef]

26. Panhwar, Q.A.; Radziah, O.; Zaharah, A.R.; Sariah, M.; Mohd Razi, I. Isolation and characterization of phosphorus solubilizing bacteria from aerobic rice. Afr. J. Biotechnol. 2012, 11, 2711-2719.

27. Finnie, J.F.; Van Staden, J. Effect of seed weed concentrate and applied hormones on in vitro cultured tomato roots. J. Plant Physiol. 1985, 120, 215-222. [CrossRef]

28. Döbereiner, J.; Day, J.M. Associative symbioses in tropical grasses. In Characterization of Microorganisms and Dinitrogen-Fixing Sites: Proceedings of the First International Symposium on N2-fixation; Newton, W.E., Nyman, C.J., Eds.; Washington University Press: Washington, DC, USA, 1976; Volume 2, pp. 518-538.

29. Kokal, H. The origin of phosphorus in iron-making raw materials and methods of removal-A review. In Proceedings of the Sixty-third Annual Meeting Minnesota Section AIME, Duluth, MN, USA, 18 January 1990; pp. 225-257.

30. Gupta, R.; Singal, R.; Shankar, A.; Kuhad, R.C.; Saxena, R.K. A modified plate assay for secreening phosphate solubilizing microorganisms. J. Gen. Appl. Microbiol. 1994, 40, 255-260. [CrossRef]

31. Buis, P. Bioremediation Techniques for the Removal of Phosphorus from Iron Ore. Ph.D. Thesis, Mining Engineering, Michigan Technological University, Houghton, MI, USA, 1995.

32. Nautiyal, C.S. An efficient microbiological growth medium for screening of phosphate solubilizing microorganisms. FEMS Microbiol. Lett. 1999, 170, 265-270. [CrossRef] [PubMed]

33. Hendricks, C.W.; Doyle, J.D.; Hugley, B. A new solid medium for enumerating cellulose-utilizing bacteria in soil. Appl. Environ. Microbiol. 1995, 61, 2016-2019. [CrossRef] [PubMed]

34. Edi-Premono, M.; Moawad, A.M.; Vlek, P.L.G. Effect of phosphate solubilizing Pseudomonas putida on the growth of maize and its survival in the rhizosphere. Indones. J. Crop Sci. 1996, 11, 13-23.

35. Lu, W.J.; Wang, H.T.; Yang, S.J.; Wang, Z.C.; Yong, F.N. Isolation and characterization of mesophilic cellulose-degrading bacteria from flower stalks-vegetable waste co-composting system. J. Gen. Appl. Microbiol. 2005, 51, 353-360. [CrossRef]

36. Somogyi, M. Notes on sugar determination. J. Biol. Chem. 1952, 195, 19-23.

37. Wood, T.M.; Bhat, K.M. Methods for measuring cellulase activities. Methods Enzymol. 1988, 160, 87-112.

38. Saha, S.; Roy, R.N.; Sen, S.K.; Ray, A.K. Characterization of cellulase-producing bacteria from the digestive tract of tilapia, Oreochromis mossambica (Peters) and grass carp, Ctenopharyngodon idella (Valenciennes). Aquacult. Res. 2006, 37, 380-388. [CrossRef] 
39. Soares, R.A.; Roesch, L.F.W.; Zanatta, G.; de Oliveira Camargo, F.A.; Passaglia, L.M.P. Occurrence and distribution of nitrogen fixing bacterial community associated with oat (Avena sativa) assessed by molecular and microbiological techniques. Appl. Soil Ecol. 2006, 33, 221-234. [CrossRef]

40. Bremner, J.M.; Keeney, D.R. A chemical index of soil nitrogen availability. Nature 1966, 20, 892-893.

41. Delvasto, P.; Ballester, A.; García, C.; Igual, J.M.; Muñoz, J.; González, F.; Blázquez, M. Mineral-phosphate solubilization activity of iron ore associated microflora. In Modern Multidisciplinary Applied Microbiology: Exploiting Microbes and Their Interactions; Mendez-Vilas, A., Ed.; Wiley: Hoboken, NJ, USA, 2006; pp. 241-245.

42. Murphy, J.; Riley, J.P. A modified single solution method for the determination of phosphate in natural waters. Anal. Chim. Acta. 1962, 27, 31-36. [CrossRef]

43. Cappuccino, J.G.; Sherman, N. Microbiology: A Laboratory Manual, 7th ed.; Pearson Education: San Francisco, CA, USA, 2005; p. 528.

44. Holt, J.G.; Krieg, N.R.; Sneath, P.H.A.; Staley, J.T.; Williams, S.T. Bergey's Manual of Determinative Bacteriology, 9th ed.; Lippincott Williams \& Wilkins: Baltimore, MD, USA, 1994; p. 787.

45. Garrity, G.M. Bergey's Manual of systematic bacteriology, Volume Two: The Proteobacteria, 2nd ed.; Springer: Berlin/Heidelberg, Germany, 2005; p. 310.

46. Abdul-Baki, A.A.; Anderson, J.D. Vigor determination in soybean seed by multiple criteria. Crop Sci. 1973, 13, 630-633. [CrossRef]

47. Asghar, H.N.; Zahir, Z.A.; Khaliq, A.; Arshad, M. Assessment of auxin production from rhizobacteria isolated from different varieties of rapeseed. Pak. J. Agri. Sci. 2000, 37, 101-104.

48. Kucey, R.M.N. Phosphate solubilizing bacteria and fungi in various cultivated and virgin Alberta soils. Can. J. Soil Sci. 1983, 63, 671-678. [CrossRef]

49. da Silva, K.; Nóbrega, R.S.A.; Lima, A.S.; Barberi, A.; de Souza Moreira, F.M. Density and diversity of diazotrophic bacteria isolated from Amazonian soils using N-free semi-solid media. Sci. Agric. 2011, 68, 518-525. [CrossRef]

50. Sethi, S.; Datta, A.; Lal Gupta, B.; Gupta, S. Optimization of cellulase production from bacteria isolated from soil. ISRN Biotechnol. 2013, 2013, 985685. [CrossRef]

51. Singh, S.; Moholkar, V.S.; Goyal, A. Isolation, identification, and characterization of a cellulolytic Bacillus amyloliquefaciens strain SS35 from rhinoceros dung. ISRN Microbiol. 2013, 2013, 728134. [CrossRef]

52. Ariffin, H.; Abdullah, N.; Umi Kalsom, M.S.; Shirai, Y.; Hassan, M.A. Production and characterisation of cellulase by Bacillus pumilus EB3. Int. J. Eng. Technol. 2006, 3, 47-53.

53. Sato, A.; Watanabe, T.; Unno, Y.; Purnomo, E.; Osaki, M.; Shinano, T. Analysis of diversity of diazotrophic bacteria associated with the rhizosphere of a tropical arbor, Melastoma malabathricum L. Microbes Environ. 2009, 24, 81-87. [CrossRef]

54. Supraja, Y.; Reddy, R.S.; Reddy, S.S.; Durga Rani, C.H.V. Plant growth promotion and biocontrol properties of local isolates of fluorescent Pseudomonads. J. Res. Angrau. 2011, 39, 1-5.

55. Pandey, A.; Trivedi, P.; Kumar, B.; Palni, L.M. Characterization of a phosphate solubilizing and antagonistic strain of Pseudomonas putida (B0) isolated from a subalpine location in the Indian Central Himalaya. Curr. Microbiol. 2006, 53, 102-107. [CrossRef] [PubMed]

56. Gulati, A.; Rahi, P.; Vyas, P. Characterization of phosphate-solubilizing fluorescent pseudomonads from the rhizosphere of seabuckthorn growing in the cold deserts of Himalayas. Curr. Microbiol. 2008, 56, 73-79. [CrossRef] [PubMed]

57. Song, O.R.; Lee, S.J.; Lee, Y.S.; Lee, S.C.; Kim, K.K.; Choi, Y.L. Solubilization of insoluble inorganic phosphate by Burkholderia cepacia DA23 isolated from cultivated soil. Braz. J. Microbiol. 2008, 39, 151-156. [CrossRef]

58. Chang, C.H.; Yang, S.S. Thermo-tolerant phosphate-solubilizing microbes for multi-functional biofertilizer preparation. Bioresour. Technol. 2009, 100, 1648-1658. [CrossRef]

59. Hwangbo, H.; Park, R.D.; Kim, Y.W.; Rim, Y.S.; Park, K.H.; Kim, T.H.; Suh, J.S.; Kim, K.Y. 2-Ketogluconic production and phosphate solubilization by Enterobacter intermedium. Curr. Microbiol. 2003, 47, 87-92.

60. Chen, Y.P.; Rekha, P.D.; Arun, A.B.; Shen, F.T.; Lai, W.A.; Young, C.C. Phosphate solubilizing bacteria from subtropical soil and their tricalcium phosphate solubilizing abilities. Appl. Soil Ecol. 2006, 34, 33-41. [CrossRef]

61. Compant, S.; Nowak, J.; Coenye, T.; Clement, C.; Ait Barka, E. Diversity and occurrence of Burkholderia spp. in the natural environment. FEMS Microbiol. Rev. 2008, 32, 607-626. [CrossRef] 
62. Thayer, D.W. Carboxymethylcellulase produced by facultative bacteria from the hind-gut of the termite Reticulitermes hesperus. J. Gen. Microbiol. 1978, 106, 13-18. [CrossRef]

63. Hameeda, B.; Rupela, O.; Reddy, G.; Satyavani, K. Application of plant growth-promoting bacteria associated with composts and macrofauna for growth promotion of Pearl millet (Pennisetum glaucum L.). Biol. Fert. Soils 2006, 43, 221-227. [CrossRef]

64. Reinhardt, E.L.; Ramos, P.L.; Manfio, G.P.; Barbosa, H.R.; Pavan, C.; Moreira-Filho, C.A. Molecular characterization of nitrogen-fixing bacteria isolated from Brazilian agricultural plants at São Paulo state. Braz. J. Microbiol. 2008, 39, 414-422. [CrossRef]

65. Dantur, K.; Enrique, R.; Welin, B.; Castagnaro, A.P. Isolation of cellulolytic bacteria from the intestine of Diatraea saccharalis larvae and evaluation of their capacity to degrade sugarcane biomass. AMB Express 2015, 5, 15. [CrossRef]

66. Hebbar, K.P.; Martel, M.H.; Heulin, T. Suppression of pre and post-emergence damping-off in corn by Burkholderia cepacia. Eur. J. Plant Pathol. 1998, 104, 29-36. [CrossRef]

67. Heydari, A.; Misaghi, I.J. Biocontrol activity of Burkholderia cepacia against Rhizoctonia solani in herbicide-treated soils. Plant Soil 1998, 202, 109-116. [CrossRef]

68. Cain, C.C.; Henry, A.T.; Waldo, R.H.; Casida, L.J.; Falkinham, J.O. Identification and characteristics of a novel Burkholderia strain with broad-spectrum antimicrobial activity. Appl. Environ. Microbiol. 2000, 66, 4139-4141. [CrossRef]

69. Li, W.; Roberts, D.P.; Dery, P.D.; Meyer, S.L.F.; Lohrke, S.; Lumsden, R.D.; Hebbar, K.P. Broad spectrum antibiotic activity and disease suppression by the potential biocontrol agent Burkholderia ambifaria BC-F. Crop Prot. 2002, 21, 129-135. [CrossRef]

70. Vijayasamundeeswari, A.; Vijayanandraj, S.; Paranidharan, V.; Samiyappan, R.; Velazhahan, R. Integrated management of aflatoxin B1 contamination of groundnut (Arachis hypogaea L.) with Burkholderia sp. and zimmu (Allium sativum L. x Allium cepa L.) intercropping. J. Plant Interact. 2010, 5, 59-68. [CrossRef]

71. Estrada, P.; Mavingui, P.; Cournoyer, B.; Fontaine, F.; Balandreau, J.; Caballero-Mellado, J. A N2-fixing endophytic Burkholderia sp. associated with maize plants cultivated in Mexico. Can. J. Microbiol. 2002, 48, 285-294. [CrossRef]

72. Lin, T.F.; Huang, H.I.; Shen, F.T.; Young, C.C. The protons of gluconic acid are the major factor responsible for the dissolution of tricalcium phosphate by Burkholderia cepacia CC-A174. Bioresour. Technol. 2006, 97, 957-960. [CrossRef]

73. Babu-Khan, S.; Yeo, T.C.; Martin, W.L.; Rogers, R.D.; Goldstein, A.H. Cloning of a mineral phosphate-solubilizing gene from Pseudomonas cepacia. Appl. Environ. Microbiol. 1995, 61, 972-978. [CrossRef]

74. Peix, A.; Mateos, P.F.; Rodriguez-Barrueco, C.; Martinez-Molina, E.; Velazquez, E. Growth promotion of common bean (Phaseolus vulgaris L.) by a strain of Burkholderia cepacia under growth chamber conditions. Soil Biol. Biochem. 2001, 33, 1927-1935. [CrossRef]

75. Caballero-Mellado, J.; Onofre-Lemus, J.; Estrada-De Los Santos, P.; Martinez-Aguilar, L. The tomato rhizosphere, an environment rich in nitrogen-fixing Burkholderia species with capabilities of interest for agriculture and bioremediation. Appl. Environ. Microbiol. 2007, 73, 5308-5319. [CrossRef]

76. Marra, L.M.; Oliveira, S.M.; Soares, C.R.F.S.; Moreira, F.M.S. Solubilisation of inorganic phosphates by inoculant strains from tropical legumes. Sci. Agric. 2011, 68, 603-609. [CrossRef]

77. Estrada-De Los Santos, P.; Bustillos-Cristales, R.; Caballero-Mellado, J. Burkholderia, a genus rich in plant-associated nitrogen fixers with wide environmental and geographic distribution. Appl. Environ. Microbiol. 2001, 67, 2790-2798. [CrossRef]

78. da Silva, K.; Cassetari Ade, S.; Lima, A.S.; De Brandt, E.; Pinnock, E.; Vandamme, P.; Moreira, F.M. Diazotrophic Burkholderia species isolated from the Amazon region exhibit phenotypical, functional and genetic diversity. Syst. Appl. Microbiol. 2012, 35, 253-262. [CrossRef]

79. Shigematsu, T.; Yumihara, K.; Ueda, Y.; Numaguchi, M.; Morimura, S.; Kida, K. Delftia tsuruhatensis sp. nov., a terephthalate-assimilating bacterium isolated from activated sludge. Int. J. Syst. Evol. Microbiol. 2003, 53, 1479-1483. [CrossRef]

80. Gulati, A.; Sood, S.; Rahi, P.; Thakur, R.; Chauhan, S.; Chawla, I. Diversity analysis of diazotrophic bacteria associated with the roots of tea (Camellia sinensis (L.) O. Kuntze). J. Microbiol. Biotechnol. 2011, 21, 545-555. 
81. Han, J.; Sun, L.; Dong, X.; Cai, Z.; Sun, X.; Yang, H.; Wang, Y.; Song, W. Characterization of a novel plant growth promoting bacteria strain Delftia tsuruhatensis HR4 both as a diazotroph and a potential biocontrol agent against various plant pathogens. Syst. Appl. Microbiol. 2005, 28, 66-76. [CrossRef]

82. O'Donnell, A.G.; Seasman, M.; Macrae, A.; Waite, I.; Davies, J.T. Plants and fertilisers as drivers of change in microbial community structure and function in soils. Plant Soil 2001, 232, 135-145. [CrossRef]

83. Satya, V.K.; Vijayasamundeeswari, A.; Paranidharan, V.; Velazhahan, R. Burkholderia sp. strain TNAU-1 for biological control of root rot in mung bean (Vigna radiata L.) caused by Macrophomina phaseolina. J. Plant Prot. Res. 2011, 51, 273-278. [CrossRef]

84. Egamberdieva, D.; Berg, G.; Lindstrom, K.; Rasanen, L. Alleviation of salt stress in cucumber and tomato by root colonising bacteria. In Soil Microbiology and Biotechnology; Miransari, M., Ed.; Studium Press: Houston, TA, USA, 2013; pp. 113-126.

85. Hameeda, B.; Harini, G.; Rupela, O.P.; Wani, S.P.; Reddy, G. Growth promotion of maize by phosphate-solubilizing bacteria isolated from composts and macrofauna. Microbiol. Res. 2008, 163, 234-242. [CrossRef]

86. Kang, S.M.; Khan, A.L.; Waqas, M.; Young, H.Y.; Hamayun, M.; Joo, G.J.; Shahzad, R.; Choi, K.S.; Lee, I.J. Gibberellin-producing Serratia nematodiphila PEJ1011 ameliorates low temperature stress in Capsicum anuum L. Eur. J. Soil Biol. 2015, 68, 85-93. [CrossRef]

87. Khan, M.Q.; Abbasi, M.W.; Zaki, M.J.; Khan, S.A. Evaluation of Bacillus thuringiensis isolates against root-knot nematodes following seed application in okra and mungbean. Pak. J. Bot. 2010, 42, 2903-2910.

88. Jin, F.; Ding, Y.; Ding, W.; Reddy, M.S.; Fernando, W.G.D.; Du, B. Genetic diversity and phylogeny of antagonistic bacteria against Phytophthora nicotianae isolated from tobacco rhizosphere. Int. J. Mol. Sci. 2011, 12, 3055-3071. [CrossRef]

89. James, E.K.; Moulin, L.; Klonowska, A.; de Faria, S.M.; Simon, M.F.; Chen, W.M. Beta-rhizobial symbioses with legumes. In The Seventeenth Australian Nitrogen Fixation Proceedings; Gupta, V.V.S.R., Unkovich, M., Kaiser, B.N., Eds.; Australian Society of Nitrogen Fixation: Adelaide, Australia, 2014; pp. 49-53.

90. Parker, M.A.; Wurtz, A.; Paynter, Q. Nodule symbiosis of invasive Mimosa pigra in Australia and in ancestral habitats: A comparative analysis. Biol. Invasions 2007, 9, 127-138. [CrossRef]

91. Gyaneshwar, P.; Hirsch, A.M.; Moulin, L.; Chen, W.M.; Elliott, G.N.; Bontemps, C.; Estrada-de los Santos, P.; Gross, E.; Bueno dos Reis, F., Jr.; Sprent, J.I.; et al. Legume-nodulating Betaproteobacteria: Diversity, host range, and future prospects. Mol. Plant Microbe Interact. 2011, 24, 1276-1288. [CrossRef]

92. Andrus, A.D.; Andam, C.; Parker, M.A. American origin of Cupriavidus bacteria associated with invasive Mimosa legumes in the Philippines. FEMS Microbiol. Ecol. 2012, 80, 747-750. [CrossRef]

93. Chen, W.M.; James, E.K.; Prescott, A.R.; Kierans, M.; Sprent, J.I. Nodulation of Mimosa spp. by the beta-proteobacterium Ralstonia taiwanensis. Mol. Plant Microbe Interact. 2003, 16, 1051-1061. [CrossRef]

94. Wierckx, N.; Koopman, F.; Ruijssenaars, H.J.; de Winde, J.H. Microbial degradation of furanic compounds: Biochemistry, genetics, and impact. Appl. Microbiol. Biotechnol. 2011, 92, 1095-1105. [CrossRef]

95. Rediers, H.; Vanderleyden, J.; De-Mot, R. Azotobacter Vinelandii: A Pseudomonas in disguise? Microbiology 2004, 6, 1117-1119. [CrossRef]

96. Pedraza, R.O. Recent advances in nitrogen-fixing acetic acid bacteria. Int. J. Food Microbiol. 2008, 6, $25-35$. [CrossRef] [PubMed]

97. Liu, Y.; Wang, H.; Sun, X.; Yang, H.; Wang, Y.; Song, W. Study on mechanisms of colonization of nitrogen-fixing PGPB, Klebsiella pneumonia NG14 on the root surface of rice and the formation of biofilm. Curr. Microbiol. 2011, 6, 1113-1122. [CrossRef] [PubMed]

98. Zehr, J.P. Nitrogen fixation by marine cyanobacteria. Trends Microbiol. 2011, 6, 162-173. [CrossRef] [PubMed]

99. Othman, R.; Naher, U.A.; Yusoff, S.Z. Effect of urea-N on growth and indoleacetic acid production of Stenotrophomonas maltophilia (Sb16) isolated from rice growing soils in Malaysia. Chil. J. Agr. Res. 2013, 73, 187-192. [CrossRef]

100. Park, M.; Kim, C.; Yang, J.; Lee, H.; Shin, W.; Kim, S.; Sa, T. Isolation and characterization of diazotrophic growth promoting bacteria from rhizosphere of agricultural crops of Korea. Microbiol. Res. 2005, 160, 127-133. [CrossRef]

101. Dastager, S.G.; Deepa, C.K.; Pandey, A. Potential plant growth-promoting activity of Serratia nematodiphila NII-0928 on black pepper (Piper nigrum L.). World J. Microbiol. Biotechnol. 2011, 27, 259-265. [CrossRef] 
102. Vidal-Quist, J.C.; Rogers, H.J.; Mahenthiralingam, E.; Berry, C. Bacillus thuringiensis colonises plant roots in a phylogeny-dependent manner. FEMS Microbiol. Ecol. 2013, 86, 474-489. [CrossRef]

103. Bevivino, A.; Tabacchioni, S.; Chiarini, L.; Carusi, M.V.; Del Gallo, M.; Visca, P. Phenotypic comparison between rhizosphere and clinical isolates of Burkholderia cepacia. Microbiology 1994, 140, 1069-1077. [CrossRef]

104. Yasmin, F.; Othman, R.; Sijam, K.; Saad, M.S. Characterization of beneficial properties of plant growth-promoting rhizobacteria isolated from sweet potato rhizosphere. Afr. J. Microbiol. Res. 2009, 3, 815-821.

105. Anitha, K.G.; Thangaraju, M. Growth promotion of rice seedling by Gluconacetobacter diazotrophicus under in vivo conditions. J. Cell Plant Sci. 2010, 1, 6-12.

106. Ambawade, M.S.; Pathade, G.R. Production of indole acetic acid (IAA) by Stenotrophomonas maltophilia BE25 isolated from roots of banana (Musa spp.). Int. J. Sci. Res. 2015, 4, 2644-2650.

107. Arshad, M.; Frankenberger, W.T., Jr. Microbial production of plant hormones. Plant Soil 1991, 133, 1-8. [CrossRef]

108. Prinsen, E.; Costacurta, A.; Michiels, K.; Vanderleyden, J.; Van Onckelen, H. Azospirillum brasilense indole-3-acetic acid biosynthesis: Evidence for a non-tryptophan dependent pathway. Mol. Plant Microbe Interact. 1993, 6, 609-615. [CrossRef]

109. Spaepen, S.; Vanderleyden, J. Auxin and plant-microbe interactions. Cold Spring Harb. Perspect. Biol. 2011, 3, a001438. [CrossRef]

(C) 2020 by the authors. Licensee MDPI, Basel, Switzerland. This article is an open access article distributed under the terms and conditions of the Creative Commons Attribution (CC BY) license (http://creativecommons.org/licenses/by/4.0/). 